\title{
Vínculos sociales y prácticas políticas en la frontera sur de Córdoba en una década clave: 1870-1880
}

\author{
Social ties and political practices in the south of Cordoba in a key \\ decade: $1870-1880$
}

Celia Cristina Basconzuelo*

RESUMEN

Es afirmación generalizada que el Estado central transitó un proceso de mayor consolidación a partir de la década de 1870 . Al mismo tiempo, y al interior de los estados provinciales fueron redefiniéndose también las relaciones político-administrativas entre las unidades miembros; los departamentos y municipios, para el caso cordobés. Este artículo aborda una región, el sur de la provincia de Córdoba, que hacia fines del siglo XIX se reformuló territorial y administrativamente como "departamento" pero a la vez continuaba desarrollándose en su rol de zona de "frontera", para explicar en ella la dinámica de vínculos sociales y políticos construidos. Esos vínculos anclaban en la diversidad de prácticas institucionales generadas a partir del ejercicio de las funciones públicas, (militares, judiciales, policiales, políticas) o bien de la labor misional. Esos vínculos junto a las prácticas institucionales y la defensa de los intereses locales operaban desde lo territorial; pero también estaban mediados por aquél carácter de frontera. A través de este análisis se mostrará cómo se potenciaban vínculos de distinto grado, los cuales tenían una funcionalidad social y también política, por cuanto servían como estrategia para construir poder en la región, articular relaciones con la provincia o bien instalar en la agenda gubernamental la representatividad de los intereses departamentales. Inclusive esos eslabones de la política podían irradiar su influencia al plano electoral, proporcionando a las facciones oficialistas y opositoras una ecuación que podía resultar victoriosa. La elección del departamento Río Cuarto en el sur cordobés, y la referencia temporal a la

\section{ABSTRACT}

It is widespread claim that the central government went through a process of further consolidation from the early 1870s. At the same time, and within the provincial States were redefining also politicaladministrative relations between the units members; the departments and municipalities for the Cordoba case. This article discusses a region, the south of the province of Córdoba, that towards the end of the 19th century was redrafted territorial and administratively as "Department" but at the same time continued developing its role as "border" area, to explain the dynamics of social and political links built in ella. These ties anchored in the diversity of institutional practices generated from the exercise of the public, (military, judicial, police, political) functions or the missionary work. Linkages with the institutional practices and protection of local interests operating from territorial; but were also mediated by one character of border. Through this analysis will be shown how enhance ties of varying degrees, which had a social function and also policy, inasmuch as it served as a strategy to build power in the region, articulate relations with the province either install the representativeness of the departmental interests in the Government agenda. Including these links in the policy could radiate its influence to the level of election, pro-Government and opposition factions to provide an equation that could prove victorious. The choice of Department Río Cuarto in the Córdoba south, and the time reference to the ' 70 s they respond to the interest in investigating that issue in a region that was populated from border until 1879, located at the intersection of trade routes and

*Universidad Nacional de Río Cuarto. CONICET. E-mail: cbasconzuelo2003@yahoo.com.ar 
década del "70 responden al interés por indagar aquella problemática en una región que fue poblado de frontera hasta 1879, ubicado en la intersección de rutas comerciales y donde una elite local renovada en su composición por la incorporación de cordobeses de la capital, identificada con el comercio y con la producción ganadera controlaba la estructura institucional de la ciudad y campaña. A la vez, disputaba espacios de poder en el ámbito provincial, a partir de la representación política en los órganos de gobierno estatal

Palabras Claves: Río Cuarto. Vínculos sociales. Prácticas políticas. Frontera sur de Córdoba. where a local elite renewed its composition by the incorporation of Cordoba in the capital, identified with the trade and livestock production controlled institutional of the city and campaign structure. At the same time, played spaces of power at the provincial level, after the political bodies of State Government representation

KEYWORDS: Río Cuarto. Social ties. Practical policies. South of Córdoba

\section{Introducción}

Es afirmación generalizada que el Estado central transitó un proceso de mayor consolidación a partir de la década de 1870. Al mismo tiempo, y al interior de los estados provinciales fueron redefiniéndose también las relaciones políticoadministrativas entre las unidades miembros; los departamentos y municipios, para el caso cordobés.

El sur provincial, particularmente, comenzaba a modificar fuertemente su perfil socio-demográfico y económico. Junto a este aspecto que ha sido ampliamente trabajado en la historiografía cordobesa (BEATO, 1993; CHAVES, 1997; TOGNETTI, 1999; VALDEMARCA, 2003), podemos considerar que al igual que el resto del interior, el sur se presentaba como un espacio de legitimación del poder donde había que convalidar candidaturas y articular alianzas para sostener las fórmulas gubernamentales capitalinas. Al detenernos en este aspecto se advierte que los espacios del interior estuvieron muy lejos de comportarse simplemente como escenarios articulados de manera subordinada a la maquinaria electoral capitalina. Allí también se construían vínculos sociales no sólo a partir de la sociabilidad sino también desde la institucionalidad; y esos vínculos podían ser la matriz para activar prácticas políticas y electorales cuya dinámica posicionaba a las autoridades claves del ordenamiento político-administrativo de la periférica campaña más allá de la imagen canonizada de subalternidad.

Este artículo aborda una región, el sur de la provincia de Córdoba, que hacia fines del siglo XIX se reformuló territorial y administrativamente como "departamento" 
pero a la vez continuaba desarrollándose en su rol de zona de "frontera", para explicar en ella la dinámica de vínculos sociales y políticos construidos. Esos vínculos anclaban en la diversidad de prácticas institucionales generadas a partir del ejercicio de las funciones públicas, (militares, judiciales, policiales, políticas) o bien de la labor misional. Esos vínculos junto a las prácticas institucionales y la defensa de los intereses locales operaban desde lo territorial; pero también estaban mediados por aquél carácter de frontera. A través de este análisis se mostrará cómo se potenciaban vínculos de distinto grado, los cuales tenían una funcionalidad social y también política, por cuanto servían como estrategia para construir poder en la región, articular relaciones con la provincia o bien instalar en la agenda gubernamental la representatividad de los intereses departamentales. Inclusive esos eslabones de la política podían irradiar su influencia al plano electoral, proporcionando a las facciones oficialistas y opositoras una ecuación que podía resultar victoriosa.

Cabe aclarar que si bien no dejamos de reconocerse la existencia e importancia de la comunidad ranquelina en la región, sólo nos referimos a ella en la medida que las instancias desencadenantes de contactos y conflictos en las relaciones interétnicas (política de agasajos, tratados, malones) dinamizaban vínculos y enlaces entre autoridades y vecinos.

La elección del departamento Río Cuarto en el sur cordobés, y la referencia temporal a la década del '70 responden al interés por indagar aquella problemática en una región que fue poblado de frontera hasta 1879, ubicado en la intersección de rutas comerciales y donde una elite local renovada en su composición por la incorporación de cordobeses de la capital, identificada con el comercio y con la producción ganadera controlaba la estructura institucional de la ciudad y campaña. A la vez, disputaba espacios de poder en el ámbito provincial, a partir de la representación política en los órganos de gobierno estatal (BASCONZUELO, 2009).

En razón de lo expuesto el presente artículo contiene apartados. En primer lugar, se introduce una contextualización breve de los procesos generales por los que transitó el Estado Nacional y los Estados provinciales en ese período. Seguidamente, se alude a la importancia y especificidad de Río Cuarto en tanto Villa de frontera y en el contexto provincial, incluyendo una caracterización breve de los procesos económicos y socio-demográficos que atravesaron a esa frontera en expansión desde fines de los años '70.

\section{Dinámica Provinciana en Una República Notabiliar}

El tránsito por los últimos dos decenios del siglo XIX encontró a la Argentina 
participando en un mundo occidental donde transcurrían profundos cambios, signados por la expansión del comercio mundial y la disponibilidad e internacionalización del flujo de capitales que enmarcaron el afianzamiento de un orden capitalista con nuevas dimensiones. Tributario de estos estímulos externos pero también de un fuerte consenso entre las elites políticas e intelectuales del país, y aún enfrentando disensos, había avanzado ya desde los años '60 y en los planos decisional y pragmático un proyecto modernizador. En los '80 dicho proyecto se reflejó en la transformación del país con la consolidación institucional de un Estado central, el avance lento y complejo de una economía capitalista con signo dependiente y el despliegue de una sociedad dinámica y también compleja.

Una parte importante de nuestra historiografía nacional ha referido cómo en ese tránsito que se desenvolvió entre los '60 y los '80 y junto al poder central en redefinición, las elites provincianas habrían jugado un papel menos relevante ya que obraron las tendencias centralizadoras, unidireccionales y una construcción de la estatidad "desde arriba", por eso el papel del Estado entendido como dirigente del proceso y como resultado del acuerdo entre los grupos dominantes de la época. Se trataría de un Estado centralizado que mediante medidas claves redujo las otrora poderosas autonomías, que logró articular vínculos con las gobernaciones mediante el manejo de los subsidios federales, que apelaba a la intervención federal para influir sobre aquéllas, que ordenó conforme al criterio centralizador los Territorios Nacionales. En fin, una visión que interpreta a las elites provincianas en posición subalterna al poder centralizador del Estado.

Sin embargo, el proceso fue mucho más complejo. Hubo negociaciones entre la Nación y las provincias, generadas en distintos planos: acuerdos electorales, planteados frente a las candidaturas de gobernadores donde presionaban los grupos locales; transacciones planteadas en lo institucional y que permitían a los grupos dominantes del Interior contrapesar desde adentro del Estado la posición asimétrica generada por los desequilibrios socio-económicos, por ejemplo accediendo al Senado; negociaciones entre los núcleos dirigentes regionales que cristalizó primero en la Liga de los Gobernadores (1874) y luego se encaminó a conformar una coalición política como el PAN (1881) construida sobre la base de alianzas.

La perspectiva del problema se esclarece mejor al contemplar también el campo de investigación regional. En este sentido diversos aportes provincianos han revelado cómo entre los años '70 y '80 las burguesías regionales fueron ejercitándose en la tarea de elaborar estrategias destinadas a modificar los espacios institucionales y económicos desde donde ellas operaban. Es decir, estas readecuaciones institucionales 
podrían ser interpretadas como resultado no sólo de un movimiento que se generalizaba a nivel nacional, sino también de una dinámica que obraba dentro de los marcos provincianos y que habría generado la necesidad de reformular las normativas básicas para el ordenamiento jurídico interno. Para lograrlo, cada elite provinciana resolvió cuándo y cómo avanzar sobre esas reformulaciones. ${ }^{2}$

\section{Importancia de la Frontera Sur en el Contexto Provincial}

La Villa de "la Concepción de Nuestra Señora", tal como fue bautizada en la real cédula de su fundación en 1786, se halla ubicada al sur de la provincia de Córdoba. Flanqueada hacia el noroeste por una cadena de montañas cuyas cumbres se elevan a no más de doscientos metros, la atraviesa un ancho río, descendiente de las altas cumbres y de rápido cauce que divide la ciudad en su parte norte y sur.

Tras un período en que tuvieron lugar las primeras exploraciones, allá por el último tercio del siglo XVI, y un poblamiento inicial en los comienzos del siglo XVIII, los avances más significativos se dieron bajo el impulso de la política borbónica. Así se explican el emplazamiento del fortín de la Concepción del Río Cuarto en 1782, la formación del pueblo homónimo instituido por el Marqués de Sobre Monte el 11 de noviembre de 1786 y después en 1797 la elevación del poblado al rango de Villa.

Villa y frontera aparecían por entonces como dos espacialidades que resignificarían sus roles, acortando sus relativas distancias cuando en 1825, y mediante una decisión que implicaba un sensible repliegue de la frontera hacia un punto de mayor resguardo, se trasladó la sede de la comandancia desde La Carlota a Río Cuarto.

Pero el hecho de ser una población de frontera colocaba a la Villa del Río Cuarto frente a problemáticas de diversa índole. Por un lado, la estructura demográfica según la cual presentaría fluctuaciones poblacionales recurrentes, debido obviamente al impacto de la relación por momentos conflictiva con el indígena. Así, de acuerdo a los registros censales el departamento Río Cuarto habría tardado alrededor de ocho décadas en superar los índices que mantuvieron su crecimiento poblacional por debajo de los 6.000 habitantes (CIMMINELLI, 2002). Por otro lado, el patrón de localización de los pobladores también siguió similar tendencia, es decir, habría acompañado los flujos y reflujos antes mencionados. Así advertimos que entre fines del siglo XVIII y la cuarta década del siglo XIX, el área que acogió los mayores núcleos poblacionales fueron las sierras -sector del oeste departamental- en detrimento de la llanura -área

2 En los años '60 reformaron sus cartas constitucionales Entre Ríos, Corrientes, Santiago del Estero y Jujuy. En 1873 Buenos Aires y en 1878 San Juan. En los '80 lo hicieron Salta, Catamarca, nuevamente Entre Ríos y Santiago del Estero, La Rioja. En 1895 Mendoza y en 1905 San Luis (MELO, 1967). 
centro sur y sureste. Por último, contaban también las variaciones en la composición étnica de esa población. De una etapa colonial donde el $40 \%$ de la población censada era blanca y el 50\% de color (indio, negro, mestizo, pardo y mulato), el censo de 1840 aludiría a una población mayoritariamente "libre" y escasos esclavos. Esa población considerada jurídicamente “libre” provenía de la región $(96,5 \%)$ y sólo un porcentaje ínfimo (3,5\%) eran migrantes de San Luis y Mendoza, también de Chile, Bolivia y Europa (ROMANO, 1990; CELTON, 1982).

Río Cuarto desempeñó su rol como villa fronteriza durante casi nueve décadas, según se dijo. Por su estratégica ubicación geográfica, en lo que era por entonces un corredor terrestre desde Buenos Aires a Cuyo, no es difícil explicar que sus elites dominantes aprovechasen y usufructuasen esa posición privilegiada. Por eso una de las actividades dominantes sería el comercio; la otra, la ganadería. Sin embargo, la cercanía de la frontera representaría un factor limitante para el desarrollo de ambos rubros. Por eso, al arribar a la segunda mitad del siglo XIX se aprecian desde el punto de vista productivo actividades con un desarrollo condicionado, y a sus sectores sociales representativos demandando políticas de contención en la frontera a fin de garantizarles la normal circulación de bienes y mercancías. Al mismo tiempo, se advierte que la inserción que hacendados y comerciantes tuvieron en la estructura institucional local y regional fue más que evidente. Quienes ocuparon cargos públicos en la villa y en el departamento y quienes desempeñaron funciones militares en la frontera, procedían de los sectores económicos dominantes. Los juzgados, la policía y comandancia nutrían sus cuadros con productores ganaderos. En cambio, los cargos de concejiles fueron ocupados en su mayoría por comerciantes. Otra tendencia observada fue la frecuencia en retornar a la actividad pública. Pero, como los cargos eran honoríficos en el caso municipal y judicial, y remunerados con cierta dificultad en la policía no cabría suponer que ese control institucional generase la posibilidad de un enriquecimiento personal. Más bien las situaciones descriptas obedecerían a la realidad de una pequeña aldea, donde un número muy limitado de sus pobladores sabían leer y escribir o tenían propiedad y medios para cubrir las magistraturas.

Las décadas comprendidas en el lapso 1870-1890 trajeron para el sur cordobés cambios cuantitativos y cualitativos significativos que modificaron su perfil de villa de frontera y las pautas propias que la habían definido bajo esos términos desde fines del siglo XVIII, cuando los representantes del poder borbónico instituyeron en estas tierras la creación de poblados como parte también de una estrategia fronteriza concebida al modo español. Así, desde los años '70 el paisaje urbano implicaría ir construyendo nuevos y complejos atributos que definirían a Río Cuarto como ciudad destacada 
dentro del sur cordobés. En comparación con ella, la campaña revelaría menos cambios sorprendentes; mantendría el perfil productivo ganadero y la modalidad de tenencia de la tierra. Por otra parte, tanto una como otra -ciudad y campaña- acogieron a nuevos actores portadores de sus propias legitimidades y lógicas operativas. Así, los antiguos propietarios, de origen español o criollo, dedicados al comercio y/ o la ganadería se vieron sobrepasados por una oleada de nuevos posesionarios provenientes de la región cordobesa, de provincias vecinas y extranjeros. Legitimada la presencia de estos últimos desde que el pacto constitucional de 1853 les abrió las puertas de la pampa gringa y de todo el país, desembarcaban en la región sureño-cordobesa con una lógica inversionista que podía verse acompañada o no con el asentamiento en la propiedad adquirida. Igual, en el caso de los nativos. El espacio urbano los albergó antes que la campaña, y allí se integrarían en la composición de la elite local o bien engrosarían las filas de los sectores medios. Por su parte, en el área rural operaría la llegada de la mano de obra arrendataria o estacional. Asimismo, todos esos procesos asistían al impulso que en parte provenía de un Estado consolidado, con rasgos intervencionista más que ampliamente liberal, muy diferente de aquellas fuerzas nacionales que asimiladas a una antigua política de contención de la frontera habían asistido de modo deficitario al sur cordobés. Ese Estado - central más bien que nacional todavía- había sentado soberanía en un espacio territorial del cual formaba parte el sur cordobés, entre los ríos Cuarto y Quinto, como atributo indisputable de su soberanía, y por ello mismo venía a operar bajo nuevos signos, mediante oficinas, establecimientos e instituciones que respondían a una dependencia nacional. Por último, se trataba también de la presencia de un Estado provincial quien bajo consignas capitalistas que su elite gobernante había hecho ya suyas, revelaba la intención de disputar ese espacio que el Estado nacional había colocado bajo su soberanía.

Se expresó con anterioridad que el departamento Río Cuarto contenía en su interior a la frontera. Por lo tanto, un dato clave de esta realidad eran las relaciones entre "cristianos" e indios; en este caso las tribus ranquelinas ${ }^{3}$. La relación entre ambas sociedades ha sido objeto de preocupación historiográfica, pudiendo diferenciar al respecto dos tesis prevalecientes.

\footnotetext{
3 En cuanto a la toponimia, el nombre primitivo fue ranculches y ranquelches, para derivar después en ranqueles, que en lengua araucana significaba rancul (carrizal) y che (gente o persona). En cuanto a su procedencia, emigraron desde las provincias de Arauco, Malleco, Gautín y Bío Bío, región central de Chile, desplazándose hacia Córdoba en la primera mitad del siglo XVIII, y alcanzando auge para mediados de esta centuria cuando sus dominios se extendieron a lo largo de 2.000 leguas por el sur de la provincia, sureste de San Luis y noroeste pampeano. Los caciques tenían su residencia principal en Leubucó, en territorio de la actual provincia de La Pampa, muy próximo a la frontera sur de San Luis. Para mediados de siglo XIX la población ranquel se estimaba en aproximadamente 1.500 indios.
} 
Una, la perspectiva de la confrontación permanente y la responsabilidad que en ella le cupo a los indígenas por su accionar contra las propiedades de los blancos. Desde esta tesis del conflicto se ha concebido la frontera como un área donde localizar coordenadas antagónicas: por un lado, el "circuito blanco" con sus intereses exportadores puestos en el centro de gravedad del Atlántico, y el "circuito indio" orientado hacia el Pacífico; por el otro, la estancia como unidad productiva frente a una cultura opuesta que le disputaba sus haciendas vacunas. El conflicto dominante habría tenido en la actividad de los misioneros un compás atenuador, abriendo la posibilidad de la convivencia pero hasta cierto punto, pues continuarían reproduciéndose los desniveles propios de esa competencia por el móvil ganadero. Partiendo de la misma tesis enunciada, el nudo de la controversia residiría por parte de los blancos en el ansia de ocupación de las tierras, y por parte de los indios habrían contado las fuertes rivalidades inter-étnicas y las diferencias entre los cacicazgos. En la frontera, los dos bandos en pugna habrían ensayado prácticas opuestas: la del cautiverio y robo de ganado a cargo de los indios, la de una represión planificada cometida por los blancos. Desde otra perspectiva teórica podría interpretarse el mismo problema. La frontera habría sido un espacio de interacción entre dos mundos culturales, con la marca de la conflictividad pero también del contacto pacífico, contribuyendo a ese acercamiento los contactos comerciales y los tratados. ${ }^{4}$

\section{Naturaleza y Potencialidad de los Vínculos Sociales e Institucionales}

Algunas precisiones teóricas

En coincidencia con Darío Barriera (2002) las configuraciones institucionales pueden ser pensadas como una de las instancias en donde los poderes se disputan, donde juegan las "relaciones" entre los actores sociales, sus "vínculos" y sus "negociaciones". La dinámica institucional también puede ser pensada como práctica estructurante donde la política y lo político emanan de aquellas relaciones sociales (GONZÁLEZ BERNALDO DE QUIRÓS, 2001, p. 22). Por lo tanto, la construcción de vínculos no supone necesariamente relaciones armoniosas, también la conflictividad puede ser parte de ella.

Estas nociones permitirán comprender el accionar de una elite local muy activa en la construcción de vínculos diversos, que permitieron a varios de sus

\footnotetext{
${ }^{4}$ Véase acerca de esta segunda perspectiva teórica: Levaggi, Abelardo (2000) Paz en la frontera. Historia de las relaciones diplomáticas con las comunidades indígenas en la Argentina (siglos XVI-XIX). Buenos Aires: Universidad del Museo Social Argentino. Tagmanini, Marcela (1997) "Hacia una antropología de la frontera". En: Revista Cronía, Revista de Investigación de la Facultad de Ciencias Humanas. UNRC. Año 1, Vol. 1, № 2 (pp. 124-128).
} 
miembros controlar la administración departamental. Este enfoque proporcionará una imagen distinta de la tradicionalmente sugerida donde sólo pareciera tener cabida elites capitalinas depositarias de las herramientas de decisión política y habitantes de la campaña como sujetos pasivos y receptores de las directivas impartidas. En el sur cordobés veremos cómo a partir de la dinámica operativa que caracterizaba a las instituciones civiles, militares y religiosas se construían, potenciaban y resignificaban vínculos con funcionalidad social y a la vez político-electoral.

\section{Los vínculos desde la comandancia}

La autoridad militar superior en la frontera era desde 1752 el comandante. Otras le seguían en rango subordinado: el comandante general del departamento, el comandante accidental y los comandantes de cada fuerte subalterno. En 1856 se instalaron dos figuras más de pertenencia nacional: el comisario nacional de guerra y el comandante de la circunscripción militar, bajo cuya autoridad quedaron comprendidos los territorios fronterizos de Córdoba y San Luis. Estos militares se hallaron inicialmente sujetos a las órdenes del gobernador, pero desde el momento en que comenzó a consolidarse el gobierno nacional, su dependencia se fijó respecto del Ministerio de Guerra. Luego, a lo largo de los años '70, tres figuras importantes se alternaron en la jefatura de la frontera: el coronel Lucio V. Mansilla (1869-1871); el general Julio A. Roca (1872-1878) y el coronel Eduardo Racedo (1878-1880) hasta el momento en que comenzaron a retirarse las fuerzas nacionales, y entonces el área quedó bajo la administración del gobierno cordobés; además, la presencia del Regimiento 70 de Línea.

El acceso a un voluminoso cuerpo documental que contiene las notas intercambiadas entre la comandancia de frontera con las autoridades civiles, con la gobernación de la provincia y el ministerio de guerra permite analizar su accionar pero también las problemáticas concretas del sector castrense en las líneas del río Cuarto primero, y Quinto después, inclusive las relaciones interétnicas. A la par de los informes que daban cuenta de la situación militar y poblacional de cada fuerte y fortín (deserciones, motines) se relataban los vaivenes en la política indígena y la frecuente problemática de responder a las demandas ranquelinas con "agasajos”. Estos aspectos nos suministran una perspectiva de análisis centrada ya no sólo en cuestiones militares sino en las interacciones sociales y el conjunto de acciones que debían emprender los comandantes. Mediante esta perspectiva se arriba al conocimiento de cómo y bajo cuáles instancias se construían los vínculos con los notables del lugar. 
La cotidianeidad de la política fronteriza planteaba problemas de abastecimiento que no conseguían ser resueltos con los envíos, en general muy irregulares, del gobierno provincial o nacional, y entonces se generaba esa dinámica de relaciones sociales y económicas de vasta amplitud, que excedía por cierto a la región sur. Estaban en juego no sólo el mantenimiento del ejército de línea, sino la política de agasajos de indios y la afirmación del Estado nacional en estas franjas de la frontera interior. Contener la frontera significaba al mismo tiempo llevar tranquilidad a los intereses privados, a los propietarios de ganado y a los dueños de estancias en el sur cordobés. Por eso, con frecuencia la comandancia recurría a los hacendados de la región para el abastecimiento de la tropa de los fortines, formalizando con ellos contratos de compra de ganado. En las operaciones intervenía como intermediario el juez de alzada. En las décadas anteriores del '50 y '60 se llegó a recurrir a los propietarios de ganado de otros departamentos (Calamuchita, Tercero Arriba, Tercero Abajo, Anejos y Río Segundo) y aún de otras provincias vecinas, principalmente mendocinos, santafecinos y bonaerenses; en todos los casos mediante la compra de ganado. También solían acudir a los comerciantes de la Villa, a sus tiendas y almacenes de ramos generales, para solicitarles además adelantos en dinero, convirtiéndose en deudores suyos (BASCONZUELO, 2003).

He aquí pues la matriz básica a partir de la cual cobraban entidad los vínculos anudados desde la comandancia con los sectores económicos más consolidados de la ciudad de Río Cuarto y su región.

En el caso de Mansilla, la documentación nos ilustra cómo supo cultivar influencias y prestigio entre los notables riocuartenses que perduraron aún después de su desplazamiento de la frontera, tal como lo expresara este vecino al corresponsal del diario El Eco:

[...] el presidente Sarmiento tiene el deber de asegurar el bienestar del país, de garantir la vida é intereses de sus habitantes. Asegure las fronteras si no quiere exponerse á perder su popularidad y descender como su antecesor con las maldiciones de toda una generación, que ya cometió el desacierto de quitarnos al Coronel Mansilla que era nuestra mejor garantía. Asegúrenos la frontera [...] (EC. 4/ 11/ 1870: p. 1).

Cuando Santiago de Estrada, quien había sido nombrado secretario de la Legación Argentina en Chile, pasó por Río Cuarto, se entrevistó con el coronel y de ese encuentro dejó plasmada una imagen de esas relaciones sociales y vínculos personales anudados por Mansilla desde la comandancia: 
La oficina era un mare mágnum de gentes de todas profesiones, desde la muy digna del sacerdocio, representada por venerables franciscanos del Convento local, hasta la muy productiva del comercio, encarnada por el honrado y cascarrabias proveedor de la guarnición. Lo seguían unos indiazos sucios y mal cubiertos, mujeres que imploraban gracia en nombre de sus cónyuges, viejos desocupados que iban a caza de noticias, y abuelas agradecidas que llevaban al Comandante huevos de tero y avestruz [...] Mansilla escuchaba un párrafo de los misioneros franciscanos, desesperaba a encargos al proveedor, platicaba con los indios, concedía o negaba amnistía a las mujeres, sorprendía a los buenos viejos en algún episodio que los dejaba boquiabiertos, mandaba a la cocina a las viejas, y tenía tiempo para expedir órdenes, recibir la correspondencia oficial, dictar centenares de epístolas, y atender al gran pensamiento que le preocupaba, avanzar la frontera al río Quinto (SEGRETI, 1973, p. 485-487).

Pero los vínculos sociales podían tener otro alcance cuando se trabajaban desde la institucionalidad militar y servían políticamente a las facciones oficialistas u opositoras: permitían a los comandantes construir poder y proyectarlo, o simplemente validarlos por su propia fortaleza ante la inminencia de las contiendas electorales. Este cuadro particularmente puede reconstruirse a partir de los innumerables relatos de la prensa opositora de la época, tal como lo muestra en toda su amplitud, y no solamente para el sur cordobés sino en toda la provincia, el Eco de Córdoba.

En efecto, en ocasión de los comicios para renovar el ejecutivo en noviembre de 1870 y cuando por primera vez se aplicó la Constitución reformada, el oficialismo en manos de Félix de la Peña (liberal moderado, simpatizante del mitrismo) propiciaba la candidatura de J uan Antonio Álvarez para gobernador y la de Agustín Patiño para vice; en tanto la otra fracción liberal (liberales ultras, simpatizantes del autonomismo porteño) apoyaba a Luis Vélez. Por su parte, los federales proponían al ex mandatario Alejo C. Guzmán. Ya desarrollados los comicios, el EC relataba que en Villa Nueva jefes y oficiales del ejército se habían convertidos en agentes electorales, impidieron a las autoridades que integraran la mesa. Allí, el comandante de frontera:

[...] impotente para obtener triunfos electorales se ha hecho rabioso, y su enemistad con el Juez de Alzada lo llevó a impedir a las autoridades que integraran la mesa y que procedieran á calificar para el Registro Cívico». También se comentaba que un militar subalterno, el teniente Pereyra, era el encargado de movilizar las clientelas: «confesó que traía la gente citada por su orden» y un segundo oficial, el teniente Machado «había sido intimado por el Comandante que si no venía con su gente lo habría de poner preso» (EC. 7/11/1870: p. 2, c/1). En Tercero Arriba el gobierno contaba con «la complicidad del comandante de frontera» quien citaba a los peones «para que hicieran su voluntad» (EC. 22/ 12/ 1870: p. 2, c/ 1). 
En una nueva convocatoria para elegir electores de gobernador (1873), la fuerza adherente a de la Peña se hallaba en crisis tras la muerte de su máximo líder. Sin un liderazgo local fuerte, el oficialismo apoyó el nombre de Tomás Garzón quien recogía adhesiones entre liberales y antiguos federales. Pero, nuevamente el liberalismo cordobés presentaba fisuras, de modo que se levantó una candidatura rival, la de Enrique Rodríguez, un abogado políticamente independiente quien contaba con sólidas amistades entre la facción liberal autonomista. En esa coyuntura se relataba que en Villa Nueva, el comandante fraguaba las inscripciones en el registro cívico y el día de la votación movilizó las milicias, contraviniendo así la disposición constitucional, y llegó a encarcelar a un ciudadano por resistirse a votar por los candidatos indicados por él (EC. 7/ 12/1873: p. 2, c/2). Desde el departamento Río Cuarto los corresponsales comentaban que los militares de las fuerzas nacionales allí acantonadas "conspiraban", alineados con el oficialismo, y amenazaban a los opositores con enviarlos al servicio de la frontera.

Relatos del mismo tenor se repetirían en las sucesivas convocatorias electorales, tal como se verá al mencionar la estrategia roquista hacia 1879, para revelar así cómo se trabajaba el consenso desde el clientelismo político de base rural.

En efecto, la permanencia de Julio A. Roca en la comandancia por el lapso de seis años tendría enorme significación en varios planos. Por una parte, desde ese puesto repensó la cuestión frontera, particularmente en cómo articular y expandir el espacio nacional. ${ }^{5}$ Por otro lado, en el plano privado, consolidó en Río Cuarto su núcleo familiar, cuando a poco de ocupar la comandancia contrajo enlace en Córdoba con Clara Funes, vínculo que lo acercó a las familias de renombre de la docta. Luego, se hizo estanciero comprando en Buenos Aires y mediante remate público unos campos ubicados entre Acequias y Los Cisnes. Asimismo, consolidó vínculos con distintos actores sociales. Por caso, el relato de un colono de Sampacho testimonia la confianza cultivada por el militar entre nativos y extranjeros, y cómo logró mediar ante el

\footnotetext{
${ }^{5}$ A modo de ejemplo, en 1877 escribía desde Río Cuarto a Del Viso: «Estas poblaciones (La Carlota y Reducción) permanecen desde hace muchos años estacionarios, sin señales de vida porque tienen la tierra en común y este sistema es barrera de todo progreso [...] Estas poblaciones pueden ser centro de prosperidad, ahora tienen más aspecto de tolderías que de otra cosa. Nadie siembra un grano de maíz ni planta un árbol porque no está en terreno propio» (RIVERO ASTENGO, 1944, p. 96). El diario local La Voz de Río Cuarto comentaba a raíz de una visita suya a la ciudad: «Y es justo orgullo que podemos pensar que las generaciones venideras consignaran como un timbre de honor para Río Cuarto el hecho de haber sido aquí donde el general Roca trazo los primeros esbozos de su gigantesco plan cuya realización lo llevo al elevado puesto que ocupa en la actualidad» (LVRC. 11/3/ 1886: p. 1, c/ 1).
} 
gobierno nacional para que éste sostuviera la colonia unos años más, cuando ya la colonización oficial a cargo de la provincia se agotaba como modelo alternativo:

Aquí, el ferrocarril Andino funcionaba desde hacia poco tiempo y la oficina del jefe de estación estaba en un vagón. No había ni una sola casa y las cincuenta personas que vivían en la colonia, dormían en cuevas excavadas en las barrancas que circundaban el lugar. Cansados de esta vida de privaciones, los colonos se lamentaban, pero el gobierno provincial se limitó a ofrecer la condonación de la anticipación que se les había hecho, que consistía en algunos utensilios y la comida. Por aquellos días, pasó por Sampacho el General Roca y los colonos se dirigieron a él en busca de soluciones. Entonces el gobierno federal tomó parte de las raciones de alimentos y animales que se daban a los indios afincados en Villa Mercedes y ayudó de esta manera a los colonos de Sampacho (LUCERO MORICONI, 1999, p. 165).

Convertido en un referente de prestigio social en Río Cuarto, proyectaba su protagonismo al ámbito asociativo local y así en 1873 participó de la fundación de la Biblioteca Popular. En 1875 figuraba en la nómina de los impulsores del Club Social (RIVERO ASTENGO, 1944, p. 52). Asimismo, extendió su apoyo a la Sociedad de Beneficencia de Río Cuarto, aportándole recursos, tal como lo hizo constar la presidenta de la institución en carta al padre franciscano Marcos Donati: 'La Sociedad de Beneficencia ha pedido ya la valiosa ayuda del Señor General D. Julio A. Roca quien nos la ha ofrecido con la mayor benevolencia" (LVRC. 21/ 10/ 1886: p. 2, c/ 1).

Pero fue sin duda en el plano de la política donde puede advertirse la funcionalidad de esos vínculos sociales que perfilaron claramente a un militar dispuesto a disputar el poder. Al respecto el general Ignacio H. Fotheringham que se desempeñó como secretario de Roca en la comandancia entre 1875 y 1878, afirma en sus memorias: "Verdad es que era una época de mucha actividad epistolar, pues comenzaba entonces su carrera de político y diplomático [...] Sus relaciones con los Gobernadores de las provincias de Córdoba y de Cuyo eran muy cordiales y muy sostenidas" (FOTHERINGHAM, 1999: 277).

Precisamente, el vínculo epistolar le sirvió también para consolidar redes políticas. La cantidad importante de cartas enviadas a gobernadores y hombres influyentes de las provincias del norte y cuyo, se suma a los telegramas remitidos desde la comandancia (AGNA. Sala IX). De igual significación fue el intercambio epistolar con su cuñado Juárez Celman. Suya fue la idea de formar en Córdoba "un centro de opinión" y hacia él se volcaron las miradas cuando se debatía la sucesión de Avellaneda, tal como lo relatara J uárez: 
Viso dice que el candidato para la presidencia es Ud. y él ha de trabajar con todo empeño [...] Viso parece que cada día va encontrando más aceptable la Liga con don Clímaco y nosotros se lo fomentamos porque la verdad es que el gobierno no tiene un nombre, uno sólo de esos antiguos amigos que no sirven [...] En el Senado como en la Cámara de Diputados sino fuera por unos cuantos nuestros, haría la víbora más ridícula; somos nosotros lo que en las sesiones preparatorias hemos sostenido el pabellón (RIVERO ASTENGO, 1944, p. 52, 54, 70, 83, 87).

También contó la palabra roquista en la prohijación de candidaturas legislativas, tal como le escribe a Juárez en junio de 1877: “[...] si queremos ser poderosos en el provenir conviene que nos mantengamos unidos y que todos nuestros actos lleven este sello, sobre todo en lo referente a senadurías y diputaciones nacionales" (RIVERO ASTENGO, 1944, p. 97).

Meses antes de abandonar la frontera esos vínculos se activaron para dar su apoyo al PAN cordobés, ante el repentino fallecimiento del electo gobernador Clímaco de la Peña. ${ }^{6}$ Las epístolas recibidas en la comandancia indicaban que los seguidores de del Viso querían evitar una nueva elección y pretendían movilizar tropas en su apoyo. En opinión del historiador Carlos Melo esto fue decisivo: “Roca se trasladó inmediatamente a Córdoba con el propósito de evitar una nueva elección y asegurar el gobierno a sus amigos" (MELO, 1967, p. 335). Finalmente, Antonio del Viso resultó electo vicegobernador, sin mediar la reunión de un nuevo Colegio Electoral, y J uárez Celman, ascendió a ministro de gobierno.

Poco después Roca abandonaba la comandancia para ocupar el ministerio de guerra de la Nación. Eran esos otros escenarios de la política mayor los convocantes del roquismo. Así lo habría revelado años atrás a J uárez desde Río Cuarto, al decir:

Cuando quiero guardar absoluta prescindencia de las cuestiones locales se pretende averiguar quiénes me quieren y quiénes no. Poco me importa tener mayor o menor influencia en este villorio que nada pesa en la balanza donde se deciden los destinos de la República (RIVERO ASTENGO, 1944, p. 100).

Sin embargo, y pese a estas expresiones reveladoras de cuáles eran los centros decisorios de peso en la política mayor, Roca seguiría manteniendo contacto epistolar con algunos amigos riocuartenses (RACEDO, 1965, p. 79). Esos adherentes al roquismo eran no solamente nombres criollos sino también extranjeros; así lo revela la

\footnotetext{
${ }^{6}$ Realizadas las elecciones provinciales a fines de 1876 los candidatos del PAN para la gobernación y vice-gobernación con Clímaco de la Peña y Antonio del Viso, respectivamente, habían triunfado en Córdoba. Pero don Clímaco falleció antes de ocupar la gobernación. Este era hombre de estrecha vinculación con Avellaneda; del Viso era un antiguo federal.
} 
importante recepción que le brindaron el presidente de la Sociedad Italiana Porta Pía y el del Centro Gallego cuando visitó Río Cuarto siendo ya primer mandatario (AHMRC. Departamento Ejecutivo. Caja 1886).

A parte de esa red de relaciones políticas sustentadas en el vínculo epistolar, Roca contó con el apoyo del diario local LVRC que le facilitó cultivar una imagen positiva en la opinión pública. Algunas páginas lo muestran pregonando formas de hacer política para la disputa presidencial:

[...] deben fijarse mucho en los ocho diputados que deben mandarme el año que viene. Tienen que ser amigos decididos con el estilo de Moyano, Galíndez, Bouquet, Mafrán. No sean sonsos y no nos manden tilingos que no sirven ni para Dios ni para el Diablo. El Congreso de 1880 deberá estar bien compuesto pues tiene que ser en caso de dudas y en última instancia juez de la elección presidencial (EC. 11/11/ 1879: p. 2, c/6).

Otras páginas evidencian que si bien alejado de la comandancia, Roca mantenía intacta la solidez de aquellos vínculos personales con los notables riocuartenses y que éstos serían funcionales ante la convocatoria electoral para las presidenciales. Esta vez fueron sus hermanos Ataliva y Alejandro quienes le aseguraban “Río Cuarto resulta estratégica para las de Cuyo [...] aquí todas las autoridades te pertenecen en cuerpo y alma" (EC. 11/11/1879: p. 2, c/6). Cuánto habían jugado esos vínculos para asegurarle votos cordobeses lo revelaría el mismo diario al difundir, una vez consagrado presidente y después cuando entregó el mando a J uárez, telegramas de varios vecinos destacados que eran militantes activos del PAN: "Los vecinos de Río Cuarto y amigos decididos del gran Partido Nacional felicitan á V.E. por haber cumplido fielmente su programa de paz y administracion. El hecho de haber transmitido el mando en completa paz se debe exclusivamente á la sabia politica de V.E.”. Firmaron la nota Miguel Olmos, A. M. Funes, Manuel Etchegoyen, Alejandro Roca, F.S. Albino, Emiliano Irusta, y doscientos vecinos más (LVRC. 14/ 10/ 1886: p. 2, $\mathrm{C} / 1)$.

Esta forma de hacer política en los centros urbanos periféricos a la capital de la República, que se nutría de vínculos personales, de raíz amical o parental, de la apelación a la prensa partidaria mostraba toda su fecundidad cuando el sujeto político ponía en acto su pretensión de disputar poder. Canales informales de la política, capaces de movilizar un sinnúmero de actores, legitimaban, antes que los votos, tal proyecto político.

Este cuadro de elementos que componían los instrumentos de que se valía la política, podría añadir también la funcionalidad de la matriz vertical que presentaba el 
ejército cuando frente a las instancias electorales donde se jugaba la ponderación de electores del PAN para gobernador, se ordenaba movilizar soldados y presionar sobre las mesas electorales. Ataliva y Alejandro -hermanos de Roca- apelarían a los amigos militares roquistas cuando todavía no se había producido la división entre roquistas y juaristas ${ }^{7}$ y entonces las fuerzas de línea de la frontera que respondían a Roca, aunque el general ya no estuviera presente, actuarían como logística al servicio de una maquinaria que en 1879 y desde Córdoba debía asegurar adhesiones explícitas para la contienda nacional del año siguiente (EC. 9/11/1879: p. 1, c/3-4; 11/11/ 1879: p. 2, c/4; 14/11/ 1879: p. 1, c/1-3; 19/11/1879: p. 1, c/1-3; 20/11/1879: p. 2, c/5; 21/11/1879: p. 1, c/1-2).

El rol clave de los misioneros franciscanos

Los padres franciscanos representaban el grupo más consolidado dentro del clero reglar en la Villa de la Concepción. Arribaron aquí en 1856, provenientes de Buenos Aires pero con una larga trayectoria en materia de misionar entre los indígenas, consolidada mediante los Colegios de Propaganda FIDE. De los tres existentes en el territorio nacional, uno sería instalado en Río Cuarto.

La historiografía local resaltó inicialmente la dimensión religiosa de las relaciones que supieron forjar desde el comienzo de su acción en las tolderías (MARTINI, 1981). Otras contribuciones destacaron el rol de los franciscanos pero como soporte de las tareas militares de asentamiento y expansión (MAEDER, 2000). Pero, a partir del momento en que la antropología cultural guió los estudios sobre la frontera del río Cuarto, éstos dieron un giro hacia la hipótesis de las interacciones, mostrando a los misioneros como intermediadores en relación con diversos actores y tras diferentes objetivos (TAMAGNINI, 1995).

Por un lado, entre los indígenas y el gobierno nacional; entonces se entrevistaban con los presidentes de la nación o con sus ministros para transferirles las demandas y quejas de los caciques cuando se demoraban las entregas de agasajos acordados por los tratados. En Buenos Aires negociaban la entrega de cautivos y acompañaban las comitivas de caciques. Nuevamente en Tierra Adentro entregaban a los indígenas los artículos enviados por el gobierno, se encargaban de las diligencias que implicaba ratificar tratados de paz, como el de 1872, y ofrecían garantías de su cumplimiento en la frontera. Diferentes cartas los muestran también en calidad de

\footnotetext{
7 Fue por ejemplo lo que sucedió en las mesas de La Carlota y Achiras para las elecciones provinciales de 1879. El liberalismo cordobés se hallaba dividido, con la fórmula oficialista (Miguel J uárez Celman/Tristán Malbrán) y el liberalismo nacionalista (Cayetano Lozano/ Felipe Díaz).
} 
mediadores entre los desertores del ejército de línea y sus jefes militares, revelándose aquí cuánto podían capitalizar en la frontera su prestigio social y su influencia sobre los comandantes

Dentro de este papel de intermediación, cabe destacar la negociación, rescate y pago de cautivos que los frailes se ocupaban personalmente de concertar; instancia por lo demás reveladora de los vínculos sellados con las familias locales. Pero también de vínculos extendidos, pues nos encontramos con una cantidad importante de cartas o telegramas entre Fray Marcos Donati y padres, esposas o madres de cautivos con procedencia no sólo de Río Cuarto y la frontera sur (La Carlota), sino también de Córdoba, Villa Nueva, Rosario y distintas localidades de la provincia de Buenos Aires. También hombres influyentes de otras ciudades que escribían a los padres franciscanos, como Manuel García, de Rosario, quien «a pedido de una familia desgraciada», los Alustiza, requería de la intervención de Marcos Donati para rescatar cautivos. Colonos santafecinos no escaparon a esta amplia red de intermediación que ofrecían los franciscanos, elevando epistolarmente sus pedidos desesperados para lograr el rescate de familiares arrebatados por las incursiones ranquelinas a la provincia vecina. A esa red se sumaron autoridades consulares francesas, desde Rosario, clamando por ciudadanos de esa nacionalidad en poder de las tribus.

La participación de las mujeres intercediendo ante los frailes es igualmente para destacar. Por ejemplo, Mercedes Soria escribía desde Río Cuarto al padre Donati: "En esta fecha escribo a un Sandalio Quintero que tiene mucha relación con el indio que tiene a mi hijo para que se ponga de acuerdo con Usted en el modo de poderlo sacar" (TAMAGNINI, 1995, p. 157). Carmen Alustiza, desde Chacras del Rosario, le suplicaba por su hijo. Petrona de Cabrera le escribía desde Córdoba, requiriendo por su esposo. Catalina Ochoa -desde Reducción- luchaba por su hija cautiva. Inés Funes, desde Villa Nueva, por su esposo e hijos; también desde este punto de la provincia lo hacía Gregoria Garzón de Irigoyen pidiendo por los hijos de una familia amiga. J isdela de Amparan, mendocina, esperaba por el rescate de su sirvienta. Cipriana de Sáenz Peña, una mujer de la clase alta porteña, enviaba vestimenta para los rescatados de las tolderías. No será casual entonces que el padre Donati fuese llamado el "Redentor de cautivos".

Al padre Donati llegaban por vía epistolar las exhortaciones de la Sociedad de Beneficencia local así como cuantiosos desembolsos procedentes de la de Rosario y de Córdoba; aspectos que nos permiten a su vez inferir el grado de movilización de las mujeres de clase alta, sus contactos con otras Sociedades y el despliegue espacial de sus gestiones sociales. 
El contacto con los frailes servía para otros fines, no sólo humanitarios, sino relacionados con la demanda de mano de obra indígena que sería refuncionalizada en la domesticidad y destinada a las familias pudientes riocuartenses. Lo requirió así, por ejemplo, el empresario Bernardo Lacasse: "No ce olvide, lo que siempre le he encargado, una o dos indias, tengo una mui buena colocacion para ellas y si pudiera mandarmelas cirbace Ud. pedir el importe del pasaje en esa mi casa en la estacion del F.C." (TAMAGNINI, 1995, p. 292).

Este cuadro simplificado de una trama más amplia, reflejada por el epistolario franciscano, mostraría a los frailes participando en la construcción de una amplia red de relaciones sociales que obedecía en su dinámica a los códigos propios de una sociedad donde se invocaban relaciones de parentesco, de amistad, de proximidad, bajo la creencia de que estos mecanismos jugaban influencia decisiva al momento de activar mediaciones.

La agenda compleja que suponía esa tarea misional, no sólo evangélica, alcanzaba asimismo la dimensión de la política. Primero, actualizando las informaciones a través de los ejemplares de periódicos que llegaban a Río Cuarto y a los fuertes que los alojaban cuando los frailes iban Tierra Adentro. El padre Moysés Álvarez le diría a fray Donati desde el fuerte Sarmiento en octubre de 1879: "Es preciso amigo mio que no deje de mandarme los diarios para saber tambien nosotros los que vivimos en Sarmiento que hay más mundo fuera de éste" (TAMAGNINI, 1995, p. 129). Ambos figuraban como suscriptores del diario EC, en el primer caso, y de El Sud América en el segundo. En segundo orden cabe mencionar la vinculación con militares que hacían política, como ya se vio en el caso de Roca.

Las vinculaciones entre Julio A. Roca y los franciscanos fueron algo más complejas. En parte recorrían el plano de los vínculos amistosos. Así, para la comandancia, los frailes resultaban vitales para contener las demandas indígenas cuando no llegaban a tiempo los recursos enviados por la nación. Al respecto, le decía Roca al padre Donati luego de ocupar la comandancia: 'Digame que hay porque las comisiones de los indios no quieren esperar ni ocho dias para recibir el completo de las yeguas. Prométales que en adelante no sucederá, que es culpa de los proveedores no del Gobierno" (TAMAGNINI, 1995, p. 169). En otro momento se verá que sus mediaciones servían para mantener la paz en la frontera: «Se nos viene la pampa hacia nosotros. No seria conveniente que Ud. fuera á visitarlos?», sugería Roca al mismo fraile en mayo de 1874 (TAMAGNINI, 1995, p. 176). Luego, ellos fueron conocedores de primera mano del proyecto roquista de expansión de la frontera, tal como lo comenta el guardián del convento, Moysés Álvarez, al padre Donati en agosto de 1878: “[...] ahora 
que Roca quiere sacar la Frontera al Sud muy lejos, si nada hubiera siempre seria prudente esperar hasta ver en que queda ese proyecto, pues unos dicen que se llevará a cabo y otros que es imposible" (TAMAGNINI, 1995, p. 117). Por su parte, la comandancia acogía todos los emisarios de los franciscanos; así lo hacía saber Roca a Donati, en enero de 1876: "No tenga pues cuidado y siempre que quiera recomendarme algún protegido, hágalo en la seguridad que haré siempre cuanto pueda pues sabe cuanto le aprecio y estimo" (TAMAGNINI, 1995, p. 205). El futuro presidente, poco antes de abandonar la frontera, no dudaría en recomendar ante las autoridades de la congregación al fraile amigo para nuevas acciones de conversión, mostrando así cuánto pesaba en ese escenario de frontera la voz de la comandancia y sus vínculos con un activo fraile de tolderías, misiones y fuertes:

Le escribo a Ud. -afirma fray Pío Bentivoglio a Marcos Donati- la presente porque el General Roca me ha insistido mucho que lo haga [...] El General quisiera que Ud. se hiciera cargo de la Capellania de Indios de Sarmiento y prometo que una vez que sepa a Ud. dispuesto á admitir, desde luego le daria a Ud. de alta en condicion de tal. [...] Desearia que todo esto quedara entre nosotros dos, por razones que Ud. muy fácilmente comprenderá (TAMAGNINI, 1995, p. 233).

Hasta allí, sin embargo, los acuerdos. Tales términos de avenencia habrían sido puestos en entredicho por el prefecto de la congregación en el informe que elevó al ministerio de justicia de la Nación, una vez concluidas las misiones de 1879. Allí Moisés Álvarez relataba ciertas desavenencias entre Roca y el Padre Donati en relación con la suerte de los indios después de la anexión de tierras: «Pero ya he dicho, la intervención militar nada permite hacer. El principal obstáculo es el General Roca. Ya he dicho que era uno de aquellos a quienes más escozor daba que el $\mathrm{P}$. Donati trasladara los indios a la Reducción, porque tenia como 3 o 4000 vacas y temia que los indios le robaran algun ternero». Roca respondió a esta nota acusatoria negando tal prevención contra los ranqueles:

Las quejas que $\mathrm{V}$. formula sobre el mal trato que reciben los indios en la Frontera de S. Luis me ha llenado de sorpresa, pues el P. Marcos que está alli y que debe saber mejor y estar más interiorizado de lo que pasa bajo su inmediata vigilancia, nunca me ha dicho que se cometan tales abusos con ellos (TAMAGNINI, 1995, p. 309).

Otro motivo de desacuerdo habría surgido ante la reacción de los frailes por las visitas de inspección que realizaban agentes nacionales a los sitios donde aquellos misionaban. Al respecto comentaba el padre Donati en agosto de 1875: 
Yo no estoy muy conforme con este nombramiento, no por que yó tenga pretensiones ó aspiraciones, si nó por que por ser este novato nada ha de entender de indios y de reducciones. Puede ser que me equivoque; á mas de eso me creo yó más argentino que él, y más interés tengo yó para el bien de estos pueblos para quienes he empleado toda mi juventud, aunque con poco provecho [...] En conclusion diré que parece una bofetada que nos dán dándonos un Inspector (TAMAGNINI, 1995, p. 64).

Sin duda, estos aspectos develados por la correspondencia muestran diversos planos de la tensión en la frontera, no sólo circunspecta a la relación entre cristianos en indios. La indicación constitucional que dejaba en manos del Congreso la tarea de "promover la conversión al catolicismo de los indígenas" y que fuera ejecutada por medio de agentes eclesiásticos, también supuso controversias con los oficiales de la frontera, quienes desde el Estado representaban los otros alcances de la política sobre la frontera.

Los jueces y sus vínculos

La administración de la justicia encarnaba en autoridades unipersonales: el juez de alzada con jurisdicción en el departamento desde 1836; los jueces pedáneos actuantes en las pedanías o distritos en que se subdividía el departamento; los jueces de primera instancia desde 1838; los celadores que colaboraban con los pedáneos en las tareas de policía municipal y los comisarios de campaña, instituidos desde 1862. Duraban un año en sus cargos y sus designaciones se oficializaban desde la municipalidad.

En las últimas décadas del siglo XIX se encaró una renovación de ese elenco preliminar. Desde 1871 Río Cuarto se convertiría en distrito judicial único para el sur cordobés. Llegarían sucesivamente un Juez Letrado para todos los asuntos civiles, criminales, comerciales y mineros; un Agente Fiscal, un Defensor de Pobres, de Menores y de Ausentes; un Oficial de Justicia (ALPC. Notas y Proyectos. Cámara de Diputados. 1871. Tomo 2: fs. 146-147). Luego, en 1879 se creó el cargo de Juez de Carreras (CLD. 1879. 17/5/ 1879: 87). En 1887 arribó el primer J uez en lo Civil y el J uez de Crimen.

Respecto de quiénes estaban en condiciones de ocupar tales cargos, se esperaba fuesen vecinos 'notables' del lugar y contaran con ingresos independientes, ya que el desempeño era ad-honorem. Además debían ser alfabetos. Estas exigencias encontrarían su explicación no tanto en la idea de priorizar una selección del personal con base elitista, sino por un lado en razón de contarse con una base poblacional donde 
el nivel de alfabetización era bajísimo, una cualidad de los extranjeros más que de los nativos. Precisamente encontraremos inmigrantes que cooperaron con los juzgados pedáneos. ${ }^{8}$ Recién desde 1870 los cargos de juez de alzada, juez de primera instancia y juez pedáneo serían rentados mensualmente por parte del tesoro provincial (ALPC. 1870. Tomo 27: f. 95).

Por otra parte, las innovaciones aludidas pondrían de manifiesto la importancia que se le concedía a Río Cuarto en el marco del sur cordobés. Pero hasta allí los beneficios, pues continuarían sin resolverse una serie de problemáticas legadas. En primer lugar, la carencia de un edificio que pudiera concentrar la actividad judicial y en su lugar, entonces, la funcionalidad de domicilios particulares o bien locales alquilados. Cabe recordar que recién en 1919 se construyó el Palacio de Justicia en la ciudad de Río Cuarto. En segundo término, las demoras en remitir las normativas que se actualizaban y sancionaban en la capital de la provincia. En tercer lugar, cierta tolerancia por parte de algunos jueces para hacer cumplir las normas vigentes o bien para aplicar las multas correspondientes; situaciones que iban generando imágenes desvalorizadas de la justicia de la campaña y que otros jueces como también autoridades policiales se animaban a denunciar una vez que accedían a sus puestos. ${ }^{9}$

Los gobernadores tenían al respecto una imagen muy clara de ese desenvolvimiento judicial tan particular en las áreas de la campaña, y no dudaron en indicar que además de los factores antes señalados no faltaban las connivencias con algunos lugareños o funcionarios subalternos. Es lo que se infiere del informe elevado por el gobernador Enrique Rodríguez hacia 1876, al decir: «En los departamentos no se siente, no se conocen los beneficios de la accion de justicia. Para ello, la justicia está encerrada en este duro dilema: someterse al arbitrio, muchas veces apasionado, de jueces sin instrucción, sin consejo, sin responsabilidad y sin control; ó acudir á la capital, soportando gastos y sacrificios personales [...] Justicia inmediata, justicia pronta, justicia gratuita, justicia que reprime los abusos é impide el abandono y las

\footnotetext{
${ }^{8}$ Antonio Massolino se dirige al presidente del Consejo Ejecutor y explica que ha dejado de asistir a los jueces pedáneos en la tarea de clasificar vagos «pues mis ocupaciones no me permiten perder dias enteros inútilmente en los juzgados» (AHMRC. Departamento Ejecutivo. Caja 1875. $3 / 2 / 1875)$.

9 Así lo refiere por ejemplo el juez de primera instancia de La Carlota al presidente de la municipalidad de Río Cuarto, en agosto de 1870: « La Carlota por seis años hace que está entregada al mas completo abandono y á la accion mas desenfrenada. Desde la embriaguez hasta el robo puede decirse que esta autorisado; porque el descuido de las autoridades asi lo han permitido. En esta población no se ve sino grupos de mujeres malentretenidas qe. corren de taberna en taberna arrastrando tras si cuanto hijo de familia pueden; hasta tal punto qe. este J uzgado se declara impotente pa. poder refrenar tanta inmoralidad, y tanto escándalo [...] Pero que se puede esperar de autoridades qe. no emplean un solo centavo, jamas tienen otro qe. pertenesca al Municipio; en este Pueblo modelo de todos los Pueblos, jamas hay una multa lo qe. prueba qe. todos son santos, o el compadrage qe. ha existido entre el mandatario y el vecindario» (AHMRC. Departamento Ejecutivo. Caja 1870. 24/ 8/ 1870).
} 
parcialidades de los subalternos, esto nos esta reclamando hace tiempo la campaña». Lo reiteró el gobernador interino Figueroa en tiempos de la administración juarista: “[...] si bien en las ciudades podemos contar con la recta administración de la justicia, no sucede lo mismo en la campaña, donde confiada á jueces legos, no hay exageración en decir que carecemos casi por completo de esta indispensable garantía del órden y de los derechos del individuo" (FERREYRA, 1997, p. 88 y 189).

¿Cómo explicar entonces esa trama de vínculos que desvirtuaba el oficio de administrar la ley y que junto a ese otro repertorio de disvalores prefiguraba el emblema de una justicia poco ecuánime? Cabe aquí desentrañar a partir de las múltiples competencias asignadas, los contactos obligados con diversos actores sociales. Conocían a los propietarios a quienes les cobraban los impuestos o les asignaban peones para ser conchabados. Trataban con los 'vagos' y 'malentretenidos' a quienes perseguían para lograr su inserción como mano de obra, para ubicarlos en trabajos públicos o enviarlos a la frontera. Familiarizaban con los comandantes de frontera a quienes les entregaban los marginados sociales como reclutas para el ejército de línea y con quienes colaboraban haciéndoles llegar los recursos materiales para los fuertes y fortines. Conocían a arrieros y troperos por cuanto les cobraban impuestos de tránsito y otorgaban o denegaban permisos para la conducción de las haciendas, y a los vecinos en general cuando ejercían sus tareas de control social.

Así entonces como el plexo normativo delineó competitividades procuró también -en una sabia percepción de interceptar posibles tramas vinculares- negarles jurisprudencia cuando en los sumarios estuviesen involucradas relaciones de parentesco (Reglamento de Justicia. Capítulo XII, artículos 1o a 5o․ En: CLD. 18521870: 167). Por su parte, la voz de los vecinos -mediada por jueces peticionantes- trató de hacerse escuchar cuando el juez de primera instancia de Achiras sugirió al presidente municipal, en 1873, que se implementara un sistema de justicia electiva a cargo de los propios vecinos. ${ }^{10}$ Pero fue además en los dispositivos electorales donde quedó sellada la oclusión a toda influencia que pudiera interponerse para inducir el voto ciudadano. No resulta entonces aleatorio que al fundamentar el voto secreto dispuesto por la reforma constitucional de 1870, la comisión oficial que redactó el proyecto sindicara directamente a las autoridades de la campaña, jueces y comandantes, como eslabones de la maquinaria electoral: “El juez y el comandante de

\footnotetext{
${ }^{10}$ Allí se decía: «hasta hoy estoy aguardando quién se haga cargo del J uzgado. Espero que se digne nombrar un juez de esta por tener mucha necesidad en salir á negocios, y no me siento capaz de sufrir mas tiempo, si le parece si Ud. aquí se nombre una Comision que nombre un juez á gusto de los vecinos puede Ud. ordenarme al respecto» (AHMRC. Departamento Ejecutivo. Caja 1873. $7 / 2 / 1873)$.
} 
campaña he aquí entre nosotros los principales instrumentos y autores del despotismo. [...]Entonces, ¿qué especie de garantías puede ofrecerse a los electores” (Exposición de la reforma constitucional. 1873: 37).

$\mathrm{Si}$ ese racimo de discursos emitidos desde el poder sacralizaban una imagen poco decorosa de los funcionarios judiciales actuantes en el ámbito rural, la apelación a otras fuentes históricas como la prensa -particularmente cuando ésta desarrolla un discurso opositor- contribuye a develar el componente clave de la cadena de influencias que descendía desde el vértice oficialista y que bajo el manto de una cuestionada parcialidad de la autoridad judicial encubría los múltiples incentivos apelados por quienes eran partido de gobierno. Parece recurrente que jueces adictos estuvieran dispuestos a canonizar las situaciones electorales a favor del oficialismo, y por eso atropellasen las mesas electorales y se apoderaran de las actas. Pero a veces la imagen era otra: funcionarios rebeldes a las directivas facciosas del oficialismo que fueron destituidos de sus cargos por conocerse su filiación opositora. Lo cual indicaría que no siempre el cuadro institucional de la campaña respondía como eslabón electoral, en el sentido esperado por el elenco gobernante de la capital provincial, y que no todos los jueces tributaban a una ecuación de mandato electoral.

Policía local y policía departamental

Una autoridad de relevancia para la Villa de la Concepción en materia de seguridad fue desde su creación en 1853 la policía local. En la figura del teniente juez de policía, luego denominado sub-intendente de policía, trabajaba bajo la dependencia municipal y componía una partida con seis vigilantes.

Las atribuciones eran vastas: en lo público, cuidar del aseo y limpieza del poblado, inspeccionar el uso de la distribución de aguas en las acequias y canales, verificar la exactitud de pesas y medidas en los mercados. En relación con la moral pública, evitar los desórdenes eintervenir para frenar los juegos prohibidos. En materia de recaudación impositiva, recolectar los derechos correspondientes a los propios y arbitrios, los de tránsito para quienes transportaban ganado, los impositivos a quienes tenían puestos ambulantes y peones conchabados. En materia judicial, la policía indagaba sobre los delitos cometidos, apresaba delincuentes y trasladaba las causas al juez de primera instancia; podía también conducir los sentenciados a los fuertes de las líneas del Río Cuarto o Río Quinto. Debía impedir el robo de haciendas o los saqueos a casas particulares. En materia de control social, otorgaba la visa correspondiente a las libretas de conchabo, concedía autorizaciones para los bailes y carreras. 
En el transcurso de los años '70 hubo cambios importantes para las fuerzas de seguridad. Por un lado, vino a constituirse en soporte de la máxima autoridad política departamental cuando una vez creada la jefatura política, le fuera anexada la fuerza policial y desplazada de la órbita municipal. Por otro lado, se buscó potenciar los controles sobre la campaña al implantarse de nuevo en 1878 las comisarías de campaña, suprimidas en 1871. La decisión de ubicar 25 comisarías en el departamento Río Cuarto y sólo 8 en San J usto daría cuenta de la presión de los sectores ganaderos en el primero, frente al decidido vuelco agrícola del segundo (CLD. 1870-1873: 100). En tercer orden, se atendió a un criterio descentralizador con la disposición de otras medidas, tales como la instalación de una sub-comisaría en La Carlota, acordada por el senado provincial (CLD. 1879. 9/9/1879: 124). Ello se reforzó en 1881 con la creación de la comisaría zonal de policía, con jurisdicción sobre el río Quinto y en 1883, coincidiendo con la ley de vagancia, con las comisarías volantes. Véase aquí de qué manera ese reforzamiento del cuerpo de funcionarios coincidía con las divisiones internas que los departamentos del sur provincial experimentaban.

El desempeño policial resultaba cuestionado desde las voces gubernamentales como por parte de los vecinos y de la prensa porque, en parte, los magros recursos municipales asignados limitaban la capacidad de ampliar la planta del personal, abonar puntualmente los sueldos o renovar el armamento. Poco se modificó la situación al decretarse su pase a la jefatura política; por eso los presupuestos del gobierno provincial de 1881y 1890 incluyeron una partida destinada a la policía de Río Cuarto.

La policía, del mismo modo que los jueces, trabajaba pues en cercanías tanto de los propietarios y mercantiles como de los sectores populares. Pero, a pesar de estos vínculos evidentes no se ha constatado que pudieran ser refuncionalizados al servicio de las lógicas electorales; posiblemente porque como de hecho era autoridad subalterna a la jefatura política tendría un desdibujado un rol en las instancias que requerían movilizar con independencia a los votantes.

La municipalidad: formato administrativo y despliegue de vínculos políticos

Los años '70 y '80, en el orden de la institucionalidad municipal, dejaron la impronta de dinámica renovada, por un lado en cuanto a las nuevas autoridades creadas -concejo deliberante e intendente- y por el otro en cuanto a su jurisdicción reformulada y recortada: de la administración departamental a ocuparse sólo del distrito, es decir, del espacio que ofrecía la cobertura de los servicios municipales.

A esa dinámica y este ajuste se sumó el recorte en impuestos locales que hasta 1870 no se co-participaban con el fisco provincial, y que al derogarse este atributo y 
remitirse en su totalidad a Córdoba el derecho de marchamo, el dos mil de la contribución directa y el cinco por ciento del impuesto de patentes, se vería resentida parte de las finanzas riocuartenses. La educación primaria sería uno de esos focos vulnerables; otro la prestación de diversos servicios públicos como el alumbrado, disponibilidad del carro funerario"11, sueldos de empleados municipales, subvenciones y obras públicas. El incumplimiento de las obligaciones fiscales por parte de los vecinos situación que con frecuencia denunciaban los recaudadores locales- alimentaría paulatinamente un déficit que, si bien controlado en los años '70 y '8012, no podría ya contenerse tras la crisis generalizada de la década siguiente. Así, en el año '91 sobrevino el embargo de los bienes municipales y la paralización de las obras públicas. Medidas de coyuntura que fueron acompañadas de otras: la cesantía de empleados públicos (abogado municipal, comisario inspector y otros empleados) y la reducción del sueldo del intendente (AHMRC. Departamento Ejecutivo. 1891. 17/3/1891). De inmediato, se realizaron gestiones ante el gobierno de la provincia a fin de conseguir fondos genuinos y equilibrar las cuentas locales, pero lograr éxito. ${ }^{13}$ Recién se observaría una recuperación de los índices productivos, del comercio y reinicio de obras públicas al promediar aquella década (AHMRC. Departamento Ejecutivo. 1891-1892, 1894).

El desequilibrio registrado en las cuentas locales demandaba la búsqueda de respuestas paliativas. Aquí fue donde en razón del peso que tenían los sectores económicos mejor acomodados de la ciudad de Río Cuarto, la municipalidad habilitó un canal vincular que la ubicó como deudora de los mismos. En 1880, el monto de dicha deuda se calculaba en 2.041\$. ¿Quiénes eran esos particulares? A través de las demandas que algunos emprendieron contra la institución por la mora en saldar los préstamos se instalan los nombres de J osé V. de Alva, importante comerciante y estanciero y además titular del juzgado de primera instancia, a quien se le debía un documento por el valor de 800\$; el sub-intendente de policía prestador de 33\$; el juez de alzada, 30\$; J uan Isla, a la sazón comerciante y miembro del concejo deliberante era acreedor de $14 \$$, Fidel Argüello, comerciante, hacendado y presidente municipal, por la

${ }^{11}$ Así lo denuncia una de las comisiones internas de la municipalidad en agosto de 1872: [...] El alumbrado publico no se ha podido estender y mejorar por la total falta de recursos en que se halló esta Comicion [...] Necesitando esta Comicion de reducir en cuanto le fuese posible sus gastos, suprimió el empleo de carrero, cuya funcion la desempeño el Sepultador, mediante una asignación mensual de 4\$ (AHMRC. Departamento Ejecutivo. 1872. 15/8/ 1872).

12 Un análisis de los ingresos y egresos de la caja municipal correspondiente a los primeros años '80, refleja una estrechez financiera clara: en 1881 gastos por 75.567 pesos y un saldo acreedor de 83.954 pesos. En 1883 similar situación: 21.422,22 \$ y gastos por el valor de 20.728,47 \$, en 1890 141.816 pesos y entradas valuadas en 143.700 pesos (AHMRC. Departamento Ejecutivo. 1883).

${ }^{13}$ El concejo deliberante comisionó al intendente Semería a fin de que le expresara al gobernador sobre: la situación angustiosa porque pasan en este momento las finanzas municipales y recaiga en el mismo la proteccion indispensable para poder salvar de una ruina inmediata los intereses municipales (AHMRC. Departamento Ejecutivo. 1891. 5/ 11/ 1891). 
suma de 40\$ (AHMRC. Departamento Ejecutivo. 1880. Cálculo de deuda a cargo de la Municipalidad de Río Cuarto. 31/3/ 1870).

Los vínculos construidos por los municipales trabajaron sin equívocos en el campo de la política, contrariando o quizá revelando a claras que las prácticas estaban en tensión con las disposiciones normativas que, recordémoslo, atribuían al municipio solamente un rol gestor. Los municipales locales encontraron en la prensa local un punto de apoyo cuando se trataba de secundar al oficialismo gobernante, y apelaron a voceros alternativos de la opinión cuando se pretendía plantear un frente opositor desde el sur provincial. Así, en los '80 LVRC fue vocero del roquismo, mientras desde El Pueblo el intendente Andrés Terzaga expresó su oposición partidaria y combatió cuanto pudo al juarismo.

¿Por qué ese deslizamiento hacia la política? Un lugar de peso tuvieron las adhesiones partidarias cuando avanzó dentro del PAN el faccionalismo entre roquistas y juaristas, y frente a ellas algunos intendentes develaron sus simpatías políticas. En efecto, el primer intendente Moisés Irusta (1883) adhería a la fracción roquista; su sucesor Andrés Terzaga (1889-1890) lo hizo con el juarismo y Antonio del Valle (18901891) nuevamente se volcó hacia el roquismo. Luego, comenzarían los vínculos con los radicales como Indalecio López, intendente entre 1892 y 1894. Su propio peso, por otra parte, tuvo la defensa de la autonomía municipal sobre todo cuando el juarismo avanzó con algunas pautas centralistas como el manejo impositivo al cual ya se aludió. Al respecto, la documentación ilustra las disputas entre el intendente J osé Semería (18861889) con el jefe político Alejandro Roca por este tema, así como los entredichos entre el citado Andrés Terzaga y el jefe político Juan Álvarez. A tal punto se desató la controversia que una vez practicadas las elecciones municipales para renovar ediles en 1889 y resultando triunfante la lista opositora al juarismo, los simpatizantes de esta facción provocaron graves disturbios en Río Cuarto. Tal situación dio pretexto al gobernador Marcos Juárez para intervenir el municipio riocuartense, deponer a Terzaga y designar en su lugar y por decreto a una Comisión Municipal, resultando así totalmente alterado el diseño institucional local que la normativa legal de 1883 había consagrado. Al año siguiente se normalizó la situación al convocarse a elecciones.

Consecuentemente, el formato administrativo atribuido al municipio por el marco legal y por las convicciones de época -recordemos aquí las sugerencias de quienes habían proyectado el diagrama de poderes dentro del Estado nacional en los años '50- indudablemente no se verificaba como tal. Las propias elecciones locales para renovar ediles y elegir intendente desde 1883 abrían el campo de la acción política, dentro de la cual no sólo se sentían convocados los partidos propiamente dichos, sino 
también otras fuerzas que como en el caso riocuartense tenían peso corporativo y pretendían trasladarlo a las lides políticas. Nos referimos a los comerciantes locales y las sucesivas candidaturas que promovieron desde los años '90 a principios de $1900 .{ }^{14}$

Las jefaturas departamentales: enclave de vínculos sociales y políticos

$\mathrm{Al}$ año siguiente de haber sido instituidas por la Constitución, un decreto del poder ejecutivo provincial puso en marcha los dispositivos para la instalación de las jefaturas políticas en cada departamento. En el de Río Cuarto fue J usto Hernández su primer titular desde 1871. Cabe recordar que las condiciones exigidas para ocupar las jefaturas políticas, eran las mismas que para senador, además de ser vecino del departamento. Una correlación muy marcada entre los ocupantes de las jefaturas y quienes poseían un capital económico acumulado en base a la estancia ganadera o el comercio, es otra de las características presentada por la institución, como ya anteriormente se indicó, además de los vínculos con las asociaciones y la masonería local.

El funcionamiento de las jefaturas políticas no se agotaba en las atribuciones explicitadas por la normativa. Un copioso epistolario existente hoy en el Archivo Histórico de la Provincia y otro más modesto en el Archivo Histórico Municipal, aluden a esas directivas complementarias impartidas desde la gobernación. A ello se agrega la información aportada por el diario LVRC, quien concedía una columna permanente para dar a conocer los documentos oficiales e información en general que la jefatura política considerara podían difundirse en la opinión pública. En su conjunto esos documentos han permitido reconstruir la dinámica institucional de la jefatura y sus vínculos.

Por un lado, es para destacar los vínculos con la comandancia de frontera donde predominó en general la colaboración. ${ }^{15} \mathrm{~J}$ ustamente, la cercanía de la frontera, la

\footnotetext{
${ }^{14}$ Así se explica, por ejemplo, que en las elecciones de 1891 para elegir intendente y concejales, se presentaran tres listas, correspondiendo dos de ellas a la esfera partidaria (Roberto Hoevel, representando a los Cívicos Nacionales, resultó votado para intendente, mientras Pastor Maciel era apoyado por el Partido Radical) y una tercera que reunía adhesiones de comerciantes locales y extranjeros levantaba la candidatura del español Genaro Iglesias. La disputa de los votos, $131 \mathrm{a}$ favor del primero, 102 para el segundo y 65 para el tercero nos revela las oportunidades que inmigrantes posicionados y comerciantes encontraban -trama vincular mediante- para participar también ellos en las disputas del poder local. La confluencia exitosa de ambos grupos sosteniendo una candidatura municipal llegaría en 1894 cuando el francés Bernardo Lacase, importante hombre de negocios, resultó electo intendente con el apoyo que no provino de ninguna fuerza política sino de la lista suscripta por la corporación de comerciantes locales. Ella obtuvo 156 sufragios de los 160 emitidos. Igual situación se planteó cuando un grupo de comerciantes propuso como candidato, luego triunfante, a Alfredo Boasi quien siendo apoyado simultáneamente por el radicalismo ocupó en forma sucesiva tres intendencias, de 1896 a1905 (MAYOL LAFERRĖRE, 1997, p. 7).
} 
indefinición del límite departamental hasta 1883 y por ende la inseguridad generada por la política de contacto y conflicto con los ranqueles, explicarían los esfuerzos mancomunados. El jefe político ofrecía su apoyo ante el rumor de posibles invasiones indígenas, y en tal oportunidad brindaba indicaciones precisas a los estancieros acerca de cómo proceder para fortificar sus casas y resguardar haciendas. En otros momentos, remitía a los jefes militares los aportes materiales enviados desde la capital provincial; se comprometía a capturar desertores y a interceder por la liberación de cautivos y ordenaba movilizar la guardia nacional a requerimiento de la comandancia.

Por otro lado, y teniendo en cuenta que la estabilidad de la frontera era vital para hacendados y comerciantes, la construcción de vínculos abrazó también a estos dos grupos socio-económicos. El jefe político recibía las quejas de los estancieros cuando algunas medidas municipales alteraban el trabajo de la mano de obra; tal como ocurrió después que se concedieran varias licencias de baile y ello ocasionara que los peones de algunas estancias se ausentasen de las labores cotidianas, situación que a criterio de estos notables contribuía a "fomentar la vagancia y ocasionar graves perjuicios" (AHMRC. Departamento Ejecutivo. 1889. 4/5/ 1889). Fueron también ellos quienes le pidieron hiciera las gestiones pertinentes a fin de que pudiera instalarse una cuarta mesa electoral en la pedanía de San Bartolomé, además de las ya existentes en Villa de la Concepción, La Carlota y Achiras, instancia que les facilitaría el ejercicio de su ciudadanía política (AHPC. 1879. Tomo 7. 23/6/1879: f. 80). Frente a los propietarios de ganado, la jefatura de Río Cuarto se mostró varias veces preocupada por las incursiones que realizaban los ranqueles en el espacio comprendido entre los ríos Cuarto y Quinto, y que derivaban casi siempre en el robo de hacienda. Por su parte, los comerciantes de la ciudad y la región le hicieron llegar su petitorio a fin de que el gobierno aprobase la convertibilidad de los billetes en momentos de crisis económica, como lo fue en el período 1873-1876 (AHPC. 1877. Tomo 8. 4/9/1876: fs. 26 y v.).

$\mathrm{Si}$ los vínculos justificaban las mediaciones del jefe político ante la gobernación, tal actitud no quedaría sin recibir una contraprestación, que se tradujo en algunos momentos en apoyo explícito de esos grupos poderosos a quien estuviera al

\footnotetext{
${ }^{15}$ Hubo sin embargo episodios aislados de tensión. Por ejemplo, en tiempos de hacerse cargo de la comandancia Julio A. Roca se desató un conflicto cuando éste ordenó poner en libertad un detenido y trasladarlo a la sede de su mando. El jefe político J osé V. de Alva aprovechó para recalcarle que hasta ese momento se había guardado armonía entre las autoridades políticas y los jefes nacionales. Intervino el fiscal del Estado provincial denunciando el abuso de autoridad por parte de Roca (AHPC. Gobierno. 1873. Tomo 8: fs. 25 y v.; 29/ 1/ 1873; 6/2/ 1873: fs. 30-31).
} 
frente de la jefatura. ${ }^{16}$ En tales circunstancias se reactualizaba la solidaridad entre pares, pues esos jefes eran de su misma extracción social.

Otro momento en que volvía a reactualizarse esa solidaridad era en la instancia de proponer nombres para ocupar juzgados, comisarías de campaña o la escribanía de Río Cuarto. El jefe político apelaba entonces al círculo de elite de la ciudad y de la región. Ese gesto condescendiente hacia los notables vuelve a resaltar cuando la jefatura por sí misma decidió crear -y luego elevar tal decisión a la gobernación- una partida de comisaría de campo, con el objeto de resguardar bienes particulares y contener el delito en la campaña.

Otros actores sociales creían encontrar en la jefatura un interlocutor eficaz. A la oficina del jefe político también llegaron escritos de la presidenta de la Sociedad de Beneficencia de Río Cuarto, solicitándole una subvención para la institución que dirigía y para que interpusiera "su influencia ante el gobierno de la provincia á fin de conseguirla” (AHPC. Gobierno. 1873. Tomo 8. 18/ 7/ 1873: f. 93).

En otra circunstancia y frente al problema de la prostitución tuvo lugar una protesta conjunta de vecinos y damas de beneficencia, exhortando a la jefatura política para que adoptara medidas de control que permitiesen preservar valores en esta sociedad aldeana: "porque no es posible presenciar actos de esta manera en este pueblo, en que se insulta á la sociedad y la moral publica", expresaba el petitorio en su tramo final (AHPC. Gobierno. 1875. Tomo 9. 1/9/1875: f. 54).

Así, pues esa intermediación con los notables del lugar, hombres y mujeres, estancieros y comerciantes, generaba afinidades y vínculos sociales y otorgaba un fuerte crédito a la jefatura política frente a las restantes instituciones. Poniéndose al descubierto la solidaridad entre pares, se infería pues un aspecto que debió sorprender seguramente a las elites capitalinas, porque no sólo mediante ella quedaba al descubierto la inexactitud de los diagnósticos que suponían impensable cualquier expresión de descontento social proveniente de la campaña, sino además porque

${ }^{16}$ Por ejemplo, cuando cuestionado el primer jefe político, Justo Hernández e iniciado un proceso judicial en su contra por supuesto mal desempeño en sus funciones, lo cual derivó en la suspensión del cargo, un grupo de vecinos apelaron al derecho constitucional de opinión y de petición, recurrieron a la prensa de la capital y dirigieron una misiva al poder ejecutivo. En ella se presentaban en calidad de "ciudadanos», quienes mediante una "manifestación espontánea", y "declaración nacida de la propia voluntad" requerían la reposición del funcionario. La firmaron Ambrosio Olmos (poderoso hacendado, roquista y gobernador entre 1886 y 1888), Manuel Tissera (hacendado, frecuente abastecedor del ejército de línea, ex juez y ex funcionario de policía), Miguel Olmos (estanciero y concejal municipal en ese año '72), Emilio Blanco (concejal), Lucas Llana, Diógenes Llana, Pedro Fierro, Marcelo Argüello, S. Argüello, J osé V. de Alva (hacendado, ex juez y ex municipal), Tristán Burgos, Pedro Bouquet (concejal), Ceferino Zapata (concejal), J osé Boasi (comerciante extranjero y concejal), Antonio Massolino (extranjero) y Fray Pío Bontivoglio, guardián del Colegio San Francisco del Río IV (CLD. 1870-1873. 12-8-1872: 166; AHPC. Gobierno. 1872. Tomo 3. s/f: fs. 104-105). La indicación de sus actividades y funciones públicas proviene de nuestro registro prosopográfico, confeccionado sobre la base de datos de las fuentes inéditas. 
encontraba a esas elites locales en la defensa férrea de los intereses regionales. A tal punto esas elites lugareñas consensuaban en torno a la valoración de este criterio $u$ otros que según las coyunturas se organizaban para ponderar, que la relación con la jefatura no siempre transitaría por los carriles de la armonía. Por eso existieron ocasiones en que esas elites batallaron contra la jefatura política y las lealtades se vieron pues erosionadas. ${ }^{17}$

Más compleja en sus términos fue la relación entre la jefatura y la municipalidad riocuartense, sobre todo porque entre 1870 y 1883 se hallaron superpuestas las jurisdicciones respectivas. Frente al desenvolvimiento de la institución municipal es cierto que los jefes políticos no tenían injerencia alguna, pero eran los propios concejiles quienes en más de una ocasión los informaron acerca de las vicisitudes del cuerpo ${ }^{18}$, el estado de las finanzas municipales e inclusive llegaban a pedirle que interpusiera su gestión ante el gobierno provincial a fin de hallar soluciones para los frecuentes problemas presupuestarios.

Otra vez entonces quedaba reforzada una acción de intermediación, la cual sin embargo no ocluía conflictividades. Municipalidad y jefatura política confrontaron en varias oportunidades. La cuestión de las competencias jurisdiccionales se presenta en los primeros tiempos como el principal detonante de una serie disputas, relacionadas principalmente con designaciones y presupuesto. En efecto, el jefe político no dudaba en designar jueces cuando los juzgados quedaban acéfalos y la municipalidad demoraba en resolver su cobertura. A veces, objetaba la propuesta municipal sobre algunos nombres, cuestionándolos por su idoneidad. J efes políticos y municipales llegaron a disputarse el destino de las partidas policiales o ciertos recursos impositivos acerca de los cuales la normativa vigente resultaba poco clara. Los litigios renovaron esa conflictividad cuando fueron abolidos los juzgados pedáneos, ocasión que aprovechó la jefatura para proponer -y obtener- la instalación de comisarías pedáneas, colocadas bajo su dependencia.

${ }^{17}$ En efecto, en 1875, en ocasión de elecciones municipales un grupo de notables, entre cuya nómina figuraba J usto Hernández, denunciaron irregularidades y responsabilizaron por ello al jefe político actuante: no habiendo habido conjueces nombrados para presidir la mesa escrutadora, por no haberlos designado el Senado, unico poder á quien faculta nuestra Constitución y no el juez de alzada o el jefe político de este Departamento, como se efectuo, tomando atribuciones que ni el Ejecutivo las tiene [...]. La firmaban además Adolfo Ortiz, Juan V. de Alva, Wenceslao Tejerina, Eloy Ávila, Manuel Sánchez, Francisco Martínez, Emilio Blanco, Bernardo Lacase, Andrés Fellini, Ceferino Irusta, S. Silvani, Mariano Argüello, J ulián Maidana (AHMRC. Departamento Ejecutivo. 1875. 10/ 10/1875).

${ }^{18}$ El presidente municipal Manuel Tissera comunicaba a la jefatura política el cese en sus funciones de varios miembros del consejo deliberativo, y le solicitaba transmitiese dicha comunicación al Gobernador, a los efectos de que expidiese un decreto de convocatoria para la elección de nuevos municipales. La nota aludía a los municipales Pedro Bouquet, Saturnino Pérez, Miguel Olmos, Manuel Sánchez, Zeferino Zapata, Amadeo Miranda, Julián Maidana, Mariano Argüello y Ramón Bargas (AHPC. Gobierno. 1872. Tomo 8. 22/1/ 1872: f. 160). 
En el último lustro de los '80 los enfrentamientos fueron más ríspidos, particularmente cuando el poder ejecutivo ordenó a la jefatura política, por entonces a cargo de Alejandro Roca, ejercer un control sobre todas las ordenanzas municipales dictadas. Ocupaba por entonces el sillón municipal José Semería -1886/1889(AHMRC. 1888. 13/1/ 1888). Los conflictos se reanudaron en 1889 siendo jefe político J uan Álvarez - de tendencia juarista- mientras la intendencia estaba a cargo de Andrés Terzaga, declarado adversario político suyo.

Controversias de otro tipo mantuvieron en conflicto a las jefaturas con los juzgados. Inicialmente por ámbitos de competencia, ya que las jurisdicciones de unos y otros se superponían; aunque a medida que fueron deslindándose las respectivas competencias, esas tensiones aminoraron. Por eso, los cruces fueron más intensos en las dos primeras jefaturas (J usto Hernández, J osé Irusta) que en las siguientes. Algunas atribuciones concedidas a las jefaturas rozaban lo judicial, en el caso que se les indicaba prestar auxilio en la ejecución de las leyes y reglamentos de justicia (CLD. 1870-1873: 77). Por eso, usualmente se recordaba al jefe político "abstenerse de intervenir en asuntos que son de atribuciones de los jueces" (AHPC. Gobierno. 1873. Tomo 8. 14/4/ 1873: f. 69v.). De todos modos cuando había que reemplazar algún juez pedáneo se le requería que indicara tres posibles candidatos, lo cual de por sí entrañaba jugar otra vez en el terreno de las relaciones con los notables locales (Ibídem. 1883. Tomo 10. 25/2/ 1883: f. 245 y v.; Ibídem. 1884. Tomo 11. 11/1/ 1884: fs. 36 y v.; 1875. Tomo 9. 16/ 7/ 1875: fs. 22 y v. Ibídem. 1886. Tomo 11: f. 52).

Por su parte, los jueces denunciaron en más de una ocasión que algunos jefes políticos ponderaban candidaturas, indicaban a sus amigos para la cobertura de algún juzgado vacante o se negaban a destituir subalternos policiales cuestionados por la justicia. ${ }^{19}$ Los jefes políticos por su lado no dudaron en descargar sus críticas contra los juzgados por la lentitud con que se resolvían las causas, el incumplimiento de decretos gubernamentales y leyes de la campaña, las acefalías, la trasgresión de las reglamentaciones, los procedimientos cuestionados, o las demoras en constituirse las mesas electorales (AHPC. Gobierno. 1872-1873).

\footnotetext{
${ }^{19}$ Precisamente, el firme requerimiento del juez de primera instancia, Tomás Burgos, de destituir al jefe de la policía de la Villa de la Concepción, Benjamín Aquino, se fundaba en conductas privadas suyas que afectaban «la moral pública y las buenas costumbres de este vecindario», y agregaba en su nota al jefe político: «Siendo mui perjudicial á la moral pública encontrarse un empleado público viviendo escandalosamente con una mujer, como verdaderos casados... nos encontramos tolerando á un empleado que con solo esa condicion escandaliza a la sociedad sin rubor alguno». El entredicho se inclinó desfavorablemente tanto para el titular de la policía como para el propio juez, cuando el jefe político J osé V. Alva sugirió a la gobernación su reemplazo por cuanto «como es público algun tiempo hace sentir una grita en contra de este empleado policial», y se permitió proponer una terna de posibles reemplazantes, Pedro Fierro, Saturnino Pérez e Indalecio López. (AHPC. 1872. Tomo 8. 11/9/1872, fs. 189 y 190; Ibídem. Tomo 8. 11/9/1872, f. 188).
} 
Pero, si se indicara sólo el alcance departamental de los vínculos que aproximaban actores institucionales y sociales sin presumir la hipótesis de una articulación a su vez con los notables de la ciudad capital, presentaríamos un cuadro de las jefaturas respondiendo únicamente a una dimensión muy circunscripta de sus nexos. Algunos jefes políticos contaban con apoderados en la ciudad de Córdoba, a quienes se les encargaba gestionar el envío de dinero y para cubrir gastos de la jefatura y de la policía, contraviniendo la costumbre de que fuese el receptor de campaña el encargado de realizar dicho trámite (AHPC. Gobierno. 1872. Tomo 8. 16/2/1872, f. 158). Las relaciones políticas no dejaban de recrearse periódicamente cuando visitas ministeriales, presidenciales ${ }^{20}$ o las encabezadas por el gobernador de la provincia daban lugar a la organización de comitivas, preparación de ceremonias, encuentros que se llevaban a cabo en la sede de la jefatura política. Ya una vez alejados de la función pública se advierte cuántos lazos habían sabido cultivar, ya que los encontraremos en la condición de electores de gobernador y vice (Eliseo Lamas en 1870, Alejandro Roca en 1876), es decir, con una inserción en la instancia donde junto con representantes de otros departamentos y con la elite capitalina, resolvían las primeras candidaturas en el gobierno provincial.

En referencia a esa gestión por lo regional, advertimos que se extendía hacia el poder ejecutivo. En razón precisamente de su condición de "vecino del departamento", el jefe político se hallaba por definición comprometido con sus problemáticas y por ende trabajaba en pos de la defensa de estos intereses regionales. Así, los veremos gestionar recurrentemente para conseguir que mediante una regular política de asignación de recursos, el servicio público policial de la ciudad funcionara disponiendo de todos los medios apropiados. ${ }^{21}$ En otras, instaba para que la administración de

\footnotetext{
20 Me refiero a las visitas del ministro Vélez Sarsfield en 1873, del presidente Sarmiento en 1875 y las varias de Roca durante su mandato.

${ }^{21}$ En 1874 al solicitar que fuesen reforzadas las fuerzas de seguridad se argumentaba: «Á consecuencia de la mucha inmigración y aumento del vecindario, se hace indispensable mayor numero de policias. De poco tiempo á esta parte se suceden con frecuencia acontecimientos desagradables como el pueblo es estremo y todo el poco poblado es indispensable la mucha vigilancia, para algun tanto dar seguridad individual y á los intereses particulares». El reclamo por los sueldos de los distintos escalafones y de mayor presupuesto también será objeto de otras tantas notas de varios jefes políticos. La fundamentación es siempre la misma: gran extensión departamental, importante cantidad de población urbana y suburbana y escasez de personal policial. Ibídem. 1874. Tomo 8. Oficio del jefe político Amadeo Miranda al Ministro de Gobierno, 24/6/1874, folio 112. Ibídem. 1883. Tomo 10. Oficio del jefe político Alejandro Roca al ministro de gobierno, 23/9/1883, f. 271. Ibídem. 1888. Tomo 14. Oficio del mismo al gobernador de la provincia, f. 119. Ibídem. 1889. Tomo 18. Oficio del mismo al ministro de gobierno, 14/12/1888, f. 119. Ibídem. 1889. Tomo 18. Oficio de Juan Álvarez, al gobernador de la provincia, 22/6/1889, fs. 21-26. Ibídem. 1877. Tomo 8. Oficio del jefe político Nicanor Quenón al ministro de gobierno, 31/ 7/ 1877, fs. 29 y v. Ibídem. 1875. Oficio del mismo al ministro de gobierno. 26/11/ 1875, f. 56.
} 
justicia contase con todos los ramos necesarios a fin de acelerar las causas en trámite. ${ }^{22}$ Su intervención buscó cubrir intereses de los ciudadanos, requiriendo por ejemplo que se instalase un número mayor de mesas electorales en el departamento, teniendo en cuenta precisamente su extensión. ${ }^{23}$ Quizá el momento más significativo y revelador de la profundidad de los vínculos cultivados en el sur cordobés sea en 1883 cuando desde Río Cuarto se tuvo conocimiento de un proyecto sancionado por la cámara de diputados de la provincia que proponía dividir el departamento. Entonces, el jefe político a la cabeza, por entonces Alejandro Roca y veintisiete vecinos más —entre ellos, otro ex jefe político- rubricaron una nota dirigida al gobernador de Córdoba donde expresaban las razones para oponerse a ella. En uno de sus tramos resalta la inequívoca identidad con los intereses de la región: «Esta división territorial Excelentísmo Señor la creemos absolutamente inconveniente no sólo por las grandes dificultades que presentara para la vigilancia policial y de seguridad, como asimismo para el ejersisio regular de la justicia; sino tambien por la inmensa importancia que dicha division le quita á nuestro prospero Departamento [...]Por todos estos motivos nos permitimos dirigirnos á V.E. suplicando la interponga sus nobles oficios y valiosa influencia al objeto de que no se sancione el dicho proyecto de division territorial de este Departamento; y dejarlo en el mismo estado en que se encuentra». La firmaron veintiocho vecinos, entre ellos, Alejandro Roca, A. Vargas, Moisés Irusta, Manuel González, Juan Jorba, Antonio Massolino, César Castelotti, Amadeo Miranda, Francisco Martínez, Ambrosio Olmos (AHPC. 1883. Tomo 7. 13/10/1883, f. 88). El proyecto se detuvo en senadores, pero sólo hasta 1888 en que se avanzó decididamente sobre esa defendida identidad territorial.

Estas expresiones prueban, por otra parte, que no todas las vinculaciones con la elite cordobesa resultaron en acercamientos y asociaciones. El discurso afirma la expresión de un sentimiento de identidad local que en el caso indicado se fijó en la territorialidad y se hallaba en contrapunto con la política gubernamental. Para ésta el espacio departamental del sur debía ser refuncionalizado administrativamente, en

22 Por ejemplo, el juzgado de letras estuvo acéfalo durante algunos meses de 1872. Entonces el jefe político inició reiterados pedidos a la gobernación para que fuese repuesta la autoridad y así pudieran acelerarse la tramitación de las causas seguidas a presos retenidos en la cárcel pública. Ibídem. 1872. Tomo 8. Oficio del J efe Político del Departamento, Justo Hernández, al Ministro de Gobierno. 20/6/1872, folios 173 y v.

${ }^{23}$ Se decía en un oficio: «... La distancia recíproca que media entre la recidencia de un gran numero de sufragantes y los puntos designados para la formacion de las mesas, hacen imposible en muchas ocasiones la concurrencia de aquellos, privandose involuntariamente de un derecho que la ley les concede».Luego, entonces sugería: «Para facilitar al Pueblo el mejor medio posible, en que pueda hacer uso de sus derechos, creo de mi deber manifestar á S.S. que es de suma necesidad y alto interes la colocacion de una mesa mas en la cabeza de la Pedanía de San Bartolomé».Ibídem. 1871. Tomo 1y 6. Oficio del J efe Político del Departamento, J usto Hernández, al Ministro de Gobierno. 23/ 12/ 1871, folio 272v. 
cambio, desde la perspectiva de los vecinos ese espacio entrañaba también una cuestión de poder, básicamente de control sobre los recursos productivos que ahora se perdían en el sur de la región departamental.

Ese cruce de intereses y la labor de mediación ejercida por las jefaturas políticas no sólo se centraron en beneficio de la comuna riocuartense, alcanzaron también a las distintas pedanías comprendidas en el departamento. Así, se avaló en su momento el petitorio de cuarenta vecinos de Reducción que reclamaban el poblado fuese centro de la creación de una nueva pedanía, a fin de propender a una mayor descentralización de la administración civil y judicial (AHPC. Gobierno. 1883. Tomo 10. 3/8/1883, f. 261). En otra oportunidad, reunido el jefe político Alejandro Roca con "vecinos y amigos" de La Carlota recogió su inquietud de solicitar mensura y delineación del terreno para establecer en esa jurisdicción nuevas colonias (AHPC. 1880. Tomo 10. 29/8/1881, fs. 121 y v.).

$\mathrm{Al}$ receptar entonces ese conjunto de demandas, de vecinos y ciudadanos, los jefes políticos no sólo reflejaban su papel de intermediación, sino se mostraban actuando en un proceso ascendente de construcción de las relaciones políticas. En prevención seguramente se las implicancias de la profundidad y alcance que podían derivarse de estos vínculos, se explica la decisión del poder ejecutivo de fijar un lapso de tiempo para el ejercicio de las jefaturas. La remoción de sus titulares quedaba así en manos de quien los instituía. En comparación con otros departamentos, en el caso riocuartense esa premisa se observó, excepción hecha de la jefatura de Alejandro Roca, quien permaneció nueve años a cargo de la misma, en coincidencia con el desempeño de su hermano y después de J uárez Celman en la presidencia de la nación. ${ }^{24}$

\section{A Modo de Conclusión}

En síntesis, se ha visto cómo la institucionalidad vigente en el departamento Río Cuarto hacia fines del siglo XIX interactuaba con una dinámica de la construcción social y alrededor de ambas se generaban interacciones de todo tipo. Por eso, la activación de vínculos y enlaces en un marco socio-económico que comenzaba a transformarse para posicionar fundamentalmente a los sectores ganaderos, dueños de tierras y a los comerciantes, nativos y extranjeros; aunque por algunos años - hasta 1879- estaría impregnada por la proximidad de la frontera. Este factor potenciaba las conflictividades, procesaba las tensiones, generaba márgenes también para negociaciones y acuerdos.

${ }^{24}$ En los departamentos del norte y oeste de la provincia los jefes políticos llegaron a conservar el cargo por más tiempo, para sí y para sus allegados familiares (PAVONI, 2000). 
Al analizar la dinámica de esos vínculos vimos cómo influían en la práctica institucional muchas veces alejándola del marco legal, cómo potenciaban y resignificaban tramas de intereses; generaban espacios donde participaban miembros de la iglesia (clero reglar), así como también la prensa. Advertimos así distintas relaciones de fuerza que operaban desde lo territorial: la representatividad de las jefaturas políticas, las débiles fronteras entre gestión y política por parte del municipio, un entramado de las relaciones económicas y financieras con la región, la resistencia de vecinos frente a la fragmentación departamental. Esa dinámica que se desplegaba en el espacio departamental, se articulaba por momentos con otra que tenía como escenario a la frontera sur, donde otros actores - los indios ranqueles- podían interactuar desde el acuerdo o el conflicto con casi todos estos actores.

Mediante el análisis de las jefaturas políticas se vio también que pese a la previsibilidad de la normativa que procuraba regular el funcionamiento de las jefaturas políticas, hubo resultados esperados y a la vez desenlaces inesperados. En un sentido, porque el desenvolvimiento de la jefatura política implicaba trasladar demandas e inquietudes hacia el gobierno provincial; pero en otro sentido, vimos cómo por ejemplo los vecinos se movilizaban en instancias que interpretaban como potencialmente negativas para el desarrollo de sus intereses en la región y lo hacían en alianza con la jefatura política; resaltamos cómo la municipalidad se halló politizada por momentos. Se desenvolvían pues dinámicas en el interior provincial a partir de los vínculos sociales, que desafiaban los consensos normativos alcanzados desde las altas esferas del poder y volvían a mostrar - en el caso riocuartense- actores sociales regionales muy movilizados detrás de identidades locales referenciadas sea en clave de la defensa autonómica o de la representatividad de intereses.

En suma, se ha tratado de realizar un aporte al análisis de las configuraciones de poder en espacios locales y microregionales, desde un área de frontera en la segunda mitad del siglo XIX. El artículo confronta con visiones más generalizadas que tienden a poner de relieve el fuerte peso de la capital cordobesa sobre las realidades locales. De allí que el análisis intentó subrayar la complejidad de un proceso que articula desde la perspectiva de los vínculos sociales e institucionales la acción de diferentes actores de la época y espacio acotado de estudio.

\section{Referencia}


BARRIERA, Darío. Por el camino de la historia política: hacia una historia política configuracional. Secuencia, Mora, n. 53, p. 163-196, mayo/ agosto, 2002.

BASCONZUELO, Celia. Legitimidad y representación en la campaña y frontera sur cordobesa: su articulación con la provincia y la Confederación. 1852-1862. 2003. Tesis (Doctoral) - Universidad Nacional de Cuyo, San Rafael.

BASCONZUELO, Celia. Una elite local en las tramas constitutivas del poder local y provincial. 2009. Tesis (Maestría en Partidos Políticos). Universidad Nacional de Cuyo, San Rafael.

BEATO, Guillermo, VALDEMARCA, Laura; MOYANO, J avier Los grupos sociales dominantes en Córdoba. In: Beato, Guillermo, Grupos sociales dominantes: México y Argentina (Siglos XIX-XX). Córdoba: Dirección General de Publicaciones, 1993. p. 101176.

CELTON, Dora. La población de Córdoba en 1840. Córdoba: J unta Provincial de Historia de Córdoba. 1982. n. 9.

CHAVES, Liliana. Tradiciones y rupturas de la elite política cordobesa (1870-1880): la clave conservadora de la modernización política. Córdoba: Ferreyra, 1997.

CIMMINELLI, Nelson. Evolución socio-demográfica de la región pampeana argentina: el poblamiento del sur de la provincia de Córdoba (1813-1914). Reflexiones Geográficas: Revista del Departamento de Geografía, Río Cuarto, n. 105, p. 22-37, 2002.

FERREYRA, Ana Inés. Mensajes de los gobernadores de Córdoba a la Legislatura: 1850-1870. Córdoba: Centro de Estudios Históricos, 1997. t. 2.

FOTHERINGHAM, Ignacio $\mathrm{H}$. La vida de un soldado: reminiscencias de las fronteras. 2. ed. Buenos Aires: Ciudad Argentina, 1999.

GONZÁLEZ BERNALDO DE QUIRÓS, Pilar. Civilidad y política en los orígenes de la nación Argentina: las sociabilidades en Buenos Aires, 1829-1862. México: Fondo de Cultura Económica, 2001.

LEVAGGI, Abelardo. Paz en la frontera: historia de las relaciones diplomáticas con las comunidades indígenas en la Argentina (siglos XVI-XIX). Buenos Aires: Universidad del Museo Social Argentino, 2000.

LUCERO MORICONI, Roberto. La inmigración italiana en el sur de Córdoba, 18701920. Río Cuarto: Editorial Río Cuarto, 1999.

MAEDER, Ernesto. La vida de la Iglesia. In: ACADEMIA NACIONAL DE LA HISTORIA. Nueva Historia dela Nación Argentina. Buenos Aires: Planeta, 2000. p. 277-311.

MARTINI, Yoli A. Los franciscanos de Río IV, indios ranqueles y otros temas de la vida en la frontera (1860-1885). Madrid: Archivo Ibero-Americano, 1981.

MAYOL LAFERRÉRE, Carlos. Historia de Río Cuarto. Río Cuarto: Puntal, 1997. 
MELO, Carlos. 1967 Córdoba. 1862-1930. In: ACADEMIA NACIONAL DE LA HISTORIA. Historia Argentina contemporánea: Historia de las provincias y sus pueblos. Buenos Aires: El Ateneo, 1967. v. 4. p. 323-397.

PAVONI, Norma. Las jefaturas políticas y su incidencia en el clientelismo rural: Córdoba 1870-1890. Cuadernos de historia: Serie Economía y Sociedad, Cordoba, n. 3, p. 123-151, 2000.

RIVERO ASTENGO, Agustín. J uárez Celman: 1844-1909. Buenos Aires: Guillermo Kraft, 1944.

ROMANO, Silvia. Frontera y migración. Córdoba. 1840-1853.In: ARCONDO, Aníbal (Comp.). Ensayos de demografía histórica: Córdoba, siglos XVIII y XIX. Cordoba: Universidad Nacional de Córdoba, 1990. p. 43-59. Serie de Investigaciones. n. 44.

TAGMANINI, Marcela. Hacia una antropología de la frontera Revista Cronía: Revista de Investigación de la Facultad de Ciencias Humanas, Rio Curato, v.1, n. 2, p. 124-28, 1997.

TAMAGNINI, Marcela. Cartas de frontera: los documentos del conflicto interétnico. Rio Cuarto: Universidad Nacional de Río Cuarto, 1995.

TOGNETTI, Luis. La banca comercial en la segunda mitad del siglo XIX. Córdoba, 1860-1890. Travesía: Revista de Historia Económica y Social. 3/4, Tucumán, v. 1, p. 29-44, 1999.

VALDEMARCA, Laura. Comerciantes contra mercados: elites mercantiles y política en la Córdoba moderna. Cordoba: Universidad Nacional de Córdoba, 2003. Serie Tesis de Posgrado.

\section{Fuentes enéditas}

\section{Legislación}

Compilación de leyes, decretos, acuerdos de la excelentísima cámara de justicia y demás disposiciones de carácter público dictadas en la provincia de Córdoba (CLD). 1870-1873. 1879.

Exposición de la reforma constitucional sancionada en 1870 por el Dr. Gerónimo Cortés, diputado a la Convención Constituyente y miembro de la Comisión Redactora y de Revisión, Córdoba, Imprenta de la Escuela Tipográfica, 1873.

\section{Periódicos}

Eco de Córdoba (EC). 1870-1873.

La Voz de Río Cuarto (LVRC). 1886. 


\section{Inéditas}

Archivo General de la Nación Argentina (AGNA). Correspondencias y telegramas del Gral. Roca. Sala IX.

Archivo Histórico de la Provincia de Córdoba (AHPC). Gobierno. 1872-1883.

Archivo Histórico Municipal de Río Cuarto. (AHMRC). Departamento Ejecutivo. 18701894.

Archivo de la Legislatura de la Provincia de Córdoba (ALPC). Notas y Proyectos. Cámara de Diputados. 1870-1871.

Colaboración recibida en 11/03/2011 y aprobada en 18/ 10/2011. 